\title{
Laboratory Investigation and Modelling of the Thermal- Mechanical Properties of Soil in Shallow Mineralized Groundwater Area
}

\author{
Zhao Xia, Xiaoming Liu $\mathbb{D}^{D}$, and Jiali Gu \\ Department of Geotechnical Engineering, College of Civil Engineering, Hunan University, Changsha, China \\ Correspondence should be addressed to Xiaoming Liu; lxmcivil@hnu.edu.cn
}

Received 18 January 2019; Revised 9 July 2019; Accepted 5 October 2019; Published 4 November 2019

Academic Editor: Mauro Giudici

Copyright ( 2019 Zhao Xia et al. This is an open access article distributed under the Creative Commons Attribution License, which permits unrestricted use, distribution, and reproduction in any medium, provided the original work is properly cited.

\begin{abstract}
The capillary rise of shallow mineralized groundwater can contribute to the salinization of the soil layers. The excessive salt amounts adversely affect soil physical and mechanical properties, as well as the heat transfer performance, all of which are key factors with regard to the design of geothermal-related earth structures such as geothermal energy piles (GEP), ground source heat pumps (GSHP), and earth-air tunnel heat exchangers (EATHE). Therefore, in this study, the thermal-mechanical properties of saline soils are systematically investigated. A series of thermal and mechanical response tests were carried out under different salinity conditions, and the shear wave velocity-stress behavior of saline soil was measured using a modified oedometric cell coupled with an anchored bender element pair. Experimental results showed that saline soils generally have higher dry density and lower optimum moisture content at higher salt contents. The shear strength of saline soil increased about $5 \%$ while the salt concentrations of bulk solution increased from $0 \mathrm{~mol} / \mathrm{kg}$ to $6 \mathrm{~mol} / \mathrm{kg}$, and the shear wave velocity increased by $50 \%$ to $83 \%$ when the normal load increased from $12.5 \mathrm{kPa}$ to $250 \mathrm{kPa}$ for sodium chloride- (NaCl-) treated soil and $39 \%$ to $52 \%$ for calcium chloride- $\left(\mathrm{CaCl}_{2^{-}}\right)$treated soil. In addition, the thermal conductivity decreased by $0.121 \mathrm{~W} \mathrm{~m}^{-1} \mathrm{~K}^{-1}$ for NaCl-treated soil and $0.129 \mathrm{~W} \mathrm{~m}^{-1} \mathrm{~K}^{-1}$ for $\mathrm{CaCl}_{2}$-treated soil on average when the salt concentration increased from $0 \mathrm{~mol} / \mathrm{kg}$ to $6 \mathrm{~mol} / \mathrm{kg}$. Finally, an elastic shear modulus $\left(G_{0}\right)$ model and a thermal conductivity $(K)$ model were formulated for saline soil for the first time, and the effectiveness and feasibility of the proposed models were validated by comparisons of the model predicted values and experimental data.
\end{abstract}

\section{Introduction}

Salt accumulates in topsoil when the saline groundwater migrates upward through capillary action and evaporates in the ground surface. Soil salinization is a severe problem throughout the world. According to the United Nations Educational, Scientific and Cultural Organization (UNESCO), over 1 billion hectares of saline soils or salt-affected soils are widely distributed in nearly 100 countries and regions, especially in arid and semiarid areas [1]; many of these areas are facing severe challenges of substantial air pollution and energy shortage caused by consuming fossil fuels for heating and cooling of the buildings [2]. Therefore, the renewable geothermal energy becomes a promising alternative to achieve thermal comfort due to its low cost, high availability, stability, and minimal environment impact and can be utilized by various geothermal subsurface earth structures such as geothermal energy piles (GEP), ground source heat pumps (GSHP), earth-air tunnel heat exchangers (EATHE), borehole thermal energy storage (BTES), geological carbon dioxide sequestration and storage, and geothermal heated pavement [3-7]. The basic principle of these projects is simple: a cold fluid $\left(\mathrm{CO}_{2}\right.$ or water $)$ is injected into the buried pipe, absorbs heat from hotter surrounding soil, and then is pumped out [8]. The geothermal-related system represents an important mean to extract heat from below the earth by fluid circulation, and study on maximizing its output performance is very important. Since the soil acts as a load and heat storage system for underground geothermal structures, evaluation of the surrounding soil's thermal and mechanical 
properties is essential to the design process which plays an important role in determining the final performance and safety assessments of these geothermal earth structures.

Over the last decades, researchers carried comprehensive studies on soil properties to improve the performance of the geothermal-related earth structures. Brandl [9] presented the importance of the thermal properties of soils in the behavior of thermal-active ground structures. Demir et al. [10] found that the soil's thermal conductivity affects the performance of the ground heat exchanger. Experimental studies conducted by Darkwa et al. [11] and Bansal et al. [12] highlighted that the overall performance of the EATHE system is significantly affected by the soil thermal properties. A study conducted by Gan and Guohui [13] has shown that the performance of an earth-air tunnel greatly depends upon the heat and moisture transfer process in the soil. Laloui and Donna [14] and Zhang and He [15] emphasized the importance of thermal conductivity because it is the only soil thermal property that can directly determine the heat transfer process in soils comparing with thermal diffusivity and heat capacity properties. Gao et al. [16] established a constitutive relation of brittle rocks under thermal-mechanical coupling conditions.

However, there are few studies available on both thermal and mechanical properties of saline soils that have combined actions on the performance of the geothermal subsurface structures [16]. Thermal conductivity is an intrinsic soil property that describes its ability to conduct heat and is affected by several factors including moisture content, dry density, soil mineral components, and salts. The effects of moisture content and other physical characteristics on soil thermal conductivity have been investigated extensively [17-21], while the effects of salts on the thermal conductivity of soil have received little attention. Studies done to date have left much uncertainty. Van Rooyen and Winterkorn [22] found no noticeable effect of salt on thermal conductivity of quartz sand at high solution contents with concentrations of $\mathrm{CaCl}_{2}$ up to $0.18 \mathrm{~mol} / \mathrm{kg}$ or with $\mathrm{NaCl}$ up to $0.34 \mathrm{~mol} / \mathrm{kg}$. This is probably because quartz has the highest thermal conductivity (i.e., 7.7 to $8.4 \mathrm{~W} \mathrm{~m}^{-1} \mathrm{~K}^{-1}$ ) of all the soil minerals [23] whereas the thermal conductivities of salt solutions are much lower $\left(0.5\right.$ to $\left.0.8 \mathrm{~W} \mathrm{~m}^{-1} \mathrm{~K}^{-1}\right)$, making the salt solutions have limited effect on the thermal conductivity of quartz sand. Globus and Rozenshtok [24] concluded that the thermal conductivity of quartz sand moistened with $0.25 \mathrm{~mol} / \mathrm{kg}$ solution of the base $\mathrm{KOH}$ was lower than that of quartz sand moistened with water. However, Noborio and McInnes [25] and Nidal and Randall [17] found that the apparent thermal conductivity of soils decreased with increased $\mathrm{NaCl}$ or $\mathrm{CaCl}_{2}$ salt concentration in solution from $0.1 \mathrm{~mol} / \mathrm{kg}$ to solubility limits. The reason for this may be that their experiments were conducted on Weswood clay loam, Padina loamy sand, and Jordanian soils, which contain a significant amount of clay; flocculation and aggregation caused by the interactions of clay particles with salt ions may strongly influence the heat transfer process [25], making the thermal conductivities of salt-affected soils decrease. In addition, Farouki [26] stated that the bonds provided by the exchanged cations may make a contribution to the strength of clay. These bonds may also
TABle 1: Physical properties of kaolin clay.

\begin{tabular}{lc}
\hline Properties & Values \\
\hline$W_{\mathrm{L}}(\%)$ & 29 \\
$W_{\mathrm{P}}(\%)$ & 18.6 \\
$I_{\mathrm{P}}$ & 10.4 \\
$G_{\mathrm{S}}$ & 2.62 \\
$\rho_{\mathrm{dmax}}\left(\mathrm{g} \mathrm{cm}^{-3}\right)$ & 1.68 \\
\hline
\end{tabular}

Note: $W_{\mathrm{L}}$ : liquid limit; $W_{\mathrm{P}}$ : plastic limit; $I_{\mathrm{P}}$ : plasticity index; $G_{\mathrm{S}}$ : specific gravity; $\rho_{\mathrm{dmax}}:$ maximum dry density.

be expected to affect the heat transfer process. Noborio and McInnes [25] found that for soils with a significant amount of clay, flocculation and aggregation might be strongly influenced by the interactions of clay particles with salt ions, which in turn influence the thermal and mechanical properties of soil.

Literature review indicated that the existing studies on thermal conductivity of salt-affected soil are scarce, obsolete, and even contradictory. Therefore, a series of laboratory experiments were conducted to investigate the effects of soil salt content on the thermal-mechanical properties including compaction property, shear strength, compressibility, shear wave velocity-stress behavior, and thermal conductivity. Scanning Electron Microscopy (SEM) was also carried out to take insight into the microstructure of saline soils. A thermal probe based on the hot wire method was employed to measure the thermal conductivity of soil at various salinity conditions. By considering the soil salt content, two $G_{0}$ and $K$ models were proposed for the first time for saline soils. The model performance was also evaluated through the comparison of predicted and measured values.

\section{Experimental Program}

2.1. Materials and Sample Preparation. Laboratory experiments were performed on kaolin clay from Hengyang County, Hunan Province, which is mainly composed of albite $\left(\mathrm{Na}\left(\mathrm{AlSi}_{3} \mathrm{O}_{8}\right), 52.2 \%\right)$ and quartz $\left(\mathrm{SiO}_{2}, 41.0 \%\right)$ according to $\mathrm{X}$-ray diffraction (XRD). The basic physical properties of the kaolin clay are given in Table 1 . The salts employed in this study are the analytical reagent (AR) of sodium chloride $(\mathrm{NaCl})$ and calcium chloride anhydrous $\left(\mathrm{CaCl}_{2}\right)$, purchased from Kermel Chemical Reagent Co., Ltd. The $\mathrm{NaCl}$ and $\mathrm{CaCl}_{2}$ salts are abundant in nature and found in many saltaffected soils; thus, they were commonly employed by researchers in the literature [25]. In order to investigate the variation of mechanical and thermal properties of saline soils under different salt concentrations, the sieved and ovendried kaolin powder was mixed uniformly with a certain amount of either $\mathrm{NaCl}$ or $\mathrm{CaCl}_{2}$ solutions. Mixing was accomplished by spraying salt solution on the soil sample and shaking the mixture in an air-tight plastic bag to reduce the evaporation; the maximum water loss of $0.2 \%$ was allowed and neglected in this study. The concentrations of the salt solutions introduced to the soil were $0 \mathrm{~mol} / \mathrm{kg}$, $1.5 \mathrm{~mol} / \mathrm{kg}, 3 \mathrm{~mol} / \mathrm{kg}, 4.5 \mathrm{~mol} / \mathrm{kg}$, and $6 \mathrm{~mol} / \mathrm{kg}$ for both $\mathrm{NaCl}$ and $\mathrm{CaCl}_{2}$ solutions. Deionized water was used in the entire 
TABle 2: Physical properties of specimens used in thermal and mechanical tests.

\begin{tabular}{lcccc}
\hline Tests & Moisture content (\%) Dry density (g/cm3) & Specimen size (mm) & $\begin{array}{c}\text { Solution concentration } \\
(\mathrm{mol} / \mathrm{kg})\end{array}$ \\
\hline Standard proctor tests & From 13 to 23 & From 1.55 to 1.75 & $\Phi=102 \mathrm{H}=116$ \\
Direct shear tests & $18,20,22$ & 1.65 & $\Phi=61.88 \mathrm{H}=20$ \\
1-D compression tests and velocity-stress tests & 20 & 1.65 & $\Phi=102 \mathrm{H}=116$ \\
Thermal tests & $18,20,22$ & 1.65 & $\Phi=102 \mathrm{H}=116$ \\
\hline
\end{tabular}

Note: $\Phi$ : diameter; $H$ : height.

experimental process. After two days of equilibration in a moist room, the prepared samples were tested [17, 25]. Then, specimens were prepared under controlled dry density by compacting within different apparatus for different tests. The detailed experimental program is summarized in Table 2 for a clearer expression.

\subsection{Test Methods}

2.2.1. Standard Proctor Compaction, Direct Shear, and Compression Tests. To investigate the effects of salt on the compaction behavior of saline soils, soils with either $\mathrm{NaCl}$ or $\mathrm{CaCl}_{2}$ solutions at various concentrations and water contents were compacted by compaction hammer in a standard compaction cylinder. Standard Proctor tests were performed according to the ASTM D698 standard. The specimens were prepared in 3 lifts; the dry densities and water contents in the compaction cylinder were measured to obtain the compaction curves.

Consolidated drained (CD) direct shear tests were conducted to evaluate the shear strength of soils under different salinity conditions (ASTM D3080). The samples were allowed to consolidate during axial loading and subjected to shearing at a constant rate of $2.4 \mathrm{~mm} / \mathrm{min}$ up to the shear displacement limit of about $8 \mathrm{~mm}$ in all tests. The tests were operated under four normal stresses of $100 \mathrm{kPa}, 200 \mathrm{kPa}$, $300 \mathrm{kPa}$, and $400 \mathrm{kPa}$. Shear stress on the failure plane at failure was obtained by the following equation: $\tau=C \times R$, where $C$ is the conversion ratio, $1.923(\mathrm{kPa} / 0.01 \mathrm{~mm})$, and $R$ is the numerical reading of the dial gauge. Internal friction angle $\varphi\left({ }^{\circ}\right)$ and cohesion $c(\mathrm{kPa})$ were estimated by the Mohr-Coulomb shear strength criterion equation: $\tau=c+\sigma \tan \varphi$ [27].

A modified oedometric cell coupled with an anchored bender element pair was used for one-dimensional compression tests and velocity-stress tests of salt-affected soil samples. Cell details and the experimental setup are shown in Figure 1 (similar designs are documented in [28-30]). The seating load applied was $12.5 \mathrm{kPa}$, and the subsequent load was doubled each time until the load of $200 \mathrm{kPa}$; the maximum load was $250 \mathrm{kPa}$ due to the jumbo size of the specimens while the unloading sequence is $250 \mathrm{kPa}, 100 \mathrm{kPa}$, and $0 \mathrm{kPa}$. Note that before loading and unloading each time, the steady state, i.e., the state where excess pore water pressures are dissipated, should be reached (the vertical deformation of the specimen should be less than $0.01 \mathrm{~mm}$ per hour). Despite that the steady state was usually reached in the first $24 \mathrm{~h}$ of each loading step in this study, the duration of each step was still preset as $24 \mathrm{~h}$ considering the test convenience and the standard of the oedometer tests. When the specimens reached their steady state, shear wave tests were implemented in each load case. The underlying principle of the shear wave velocity testing technique is that a signal generator (Keysight $33210 \mathrm{~A}$ ) delivers a shear wave which is amplified by the linear amplifier (Piezo Systems EPA-104) causing mechanical vibration of the source bender element; the generated mechanical wave (shear wave) propagates through the soil sample and is eventually captured by the receiver bender element, which is connected through a filter-amplifier (KrohnHite 3362) into the digital storage oscilloscope (Keysight DSOX2004A). The time difference between the transmitted wave and the received wave displayed on the oscilloscope is considered as the travel time of the shear wave; along with which the shear wave velocity $(v)$, this time difference can be calculated with the tip-to-tip distance between the bender element pair. With the known velocity of the specimen, the elastic shear modulus $G_{0}$ (also referred to as the small strain shear modulus) can be calculated according to the following equation: $G_{0}=\rho \cdot v^{2}$, where $\rho$ is the bulk density of the specimen. Besides, the velocity-stress behavior of salt-affected samples can be analyzed with the applied vertical stress.

2.2.2. Thermal Conductivity Test. A thermal probe was used to measure the thermal conductivity of soils for the study of the thermal effect purpose. This thermal probe is a commercial thermal property analyzer, KD2 Pro (Decagon Devices Inc.). The setup for the thermal conductivity measurement and the specifications of the KD2 Pro instrument are presented in Figure 2. Its operating concept is based on the hot wire method where the thermal conductivity is calculated by monitoring the heat dissipation from a linear heat source at a given voltage (ASTM D5334). The probe consists of a heating wire (60 $\mathrm{mm}$ long and $1.28 \mathrm{~mm}$ in diameter) and a thermistor in the middle of the wire. During the measurement, the controller firstly heats the probe for $30 \mathrm{~s}$ and then calculates the thermal characteristics; water translocation can be overlooked due to the short time heating.

\section{Results and Discussions}

\subsection{Mechanical Behavior of Saline Soil}

3.1.1. Compaction Properties. Compaction curves of saline soil under different salinity conditions are shown in Figure 3. It can be observed that the maximum dry density ranged from $1.68 \mathrm{~g} / \mathrm{cm}^{3}$ to $1.83 \mathrm{~g} / \mathrm{cm}^{3}$, where the corresponding optimum 


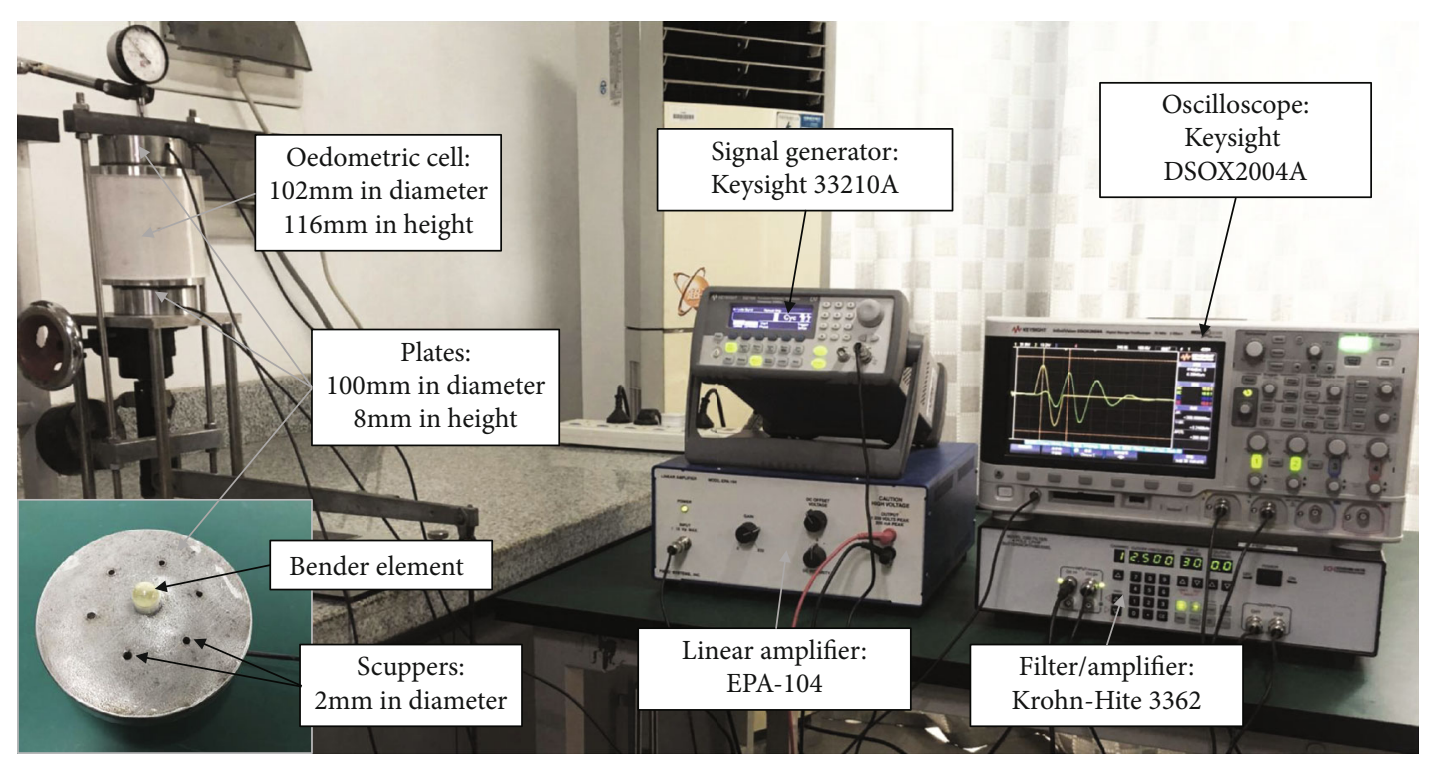

(a) Photograph of modified oedometric cell

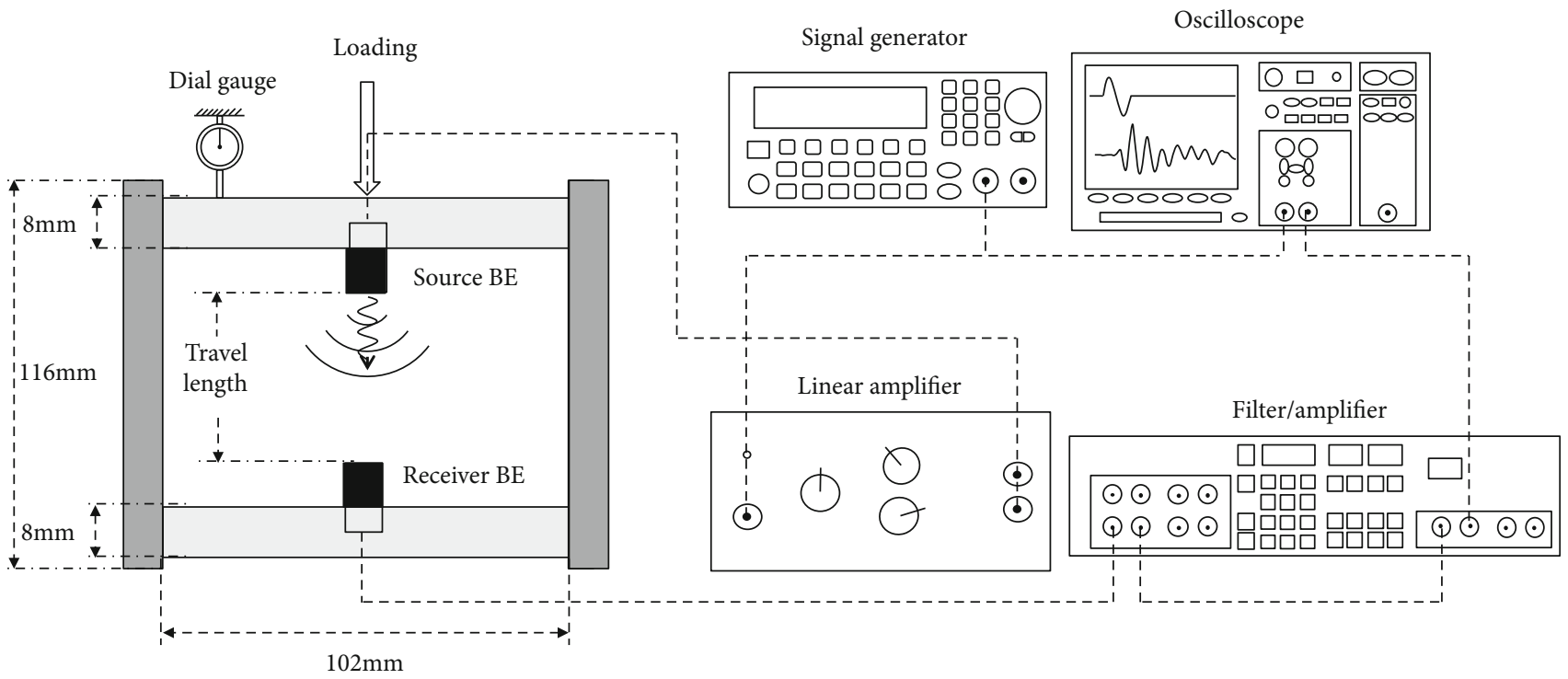

(b) Schematic of modified oedometric cell

Figure 1: Details of modified oedometric cell and experimental setup.

moisture contents are $21.2 \%$ to $17.4 \%$, respectively. This phenomenon can be explained by the theory of electric double layer (EDL). The structure of EDL is shown in Figure 4; soil particles with negative electrification provide electrostatic attraction for water molecules; such attractive force is strong enough to restrict the activity of water molecules within immovable boundaries A and B, viz., the fixed layer. The outer layer is called the diffusion layer, the thickness of which is transformable due to the longer distance from the soil particle and it is determined by the potential between $\mathrm{B}$ ( $\zeta$ potential) and $\mathrm{C}$ (zero potential). The more cations in the diffusion layer, the quicker the $\zeta$ potential decrease, thus, the thinner the diffusion layer. The cations in the bulk solution can affect the thickness of EDL. Mitchell and Soga [31] pointed out that the distribution of the charge density and electric potential in the EDL can be described by the
Poisson-Boltzmann equation, and the thickness of EDL can be expressed as

$$
\frac{1}{K}=\frac{1}{E v}\left(\frac{D k T}{8 \pi n_{0}}\right)^{1 / 2},
$$

where $1 / K$ is the thickness of EDL, $E$ is the unit electrostatic charge, $v$ is the ionic valence of the charge, $D$ is the dielectric constant of diffusion layer medium, $k$ is the Boltzmann constant $\left(k=1.23 \times 10^{-23} \mathrm{~J} / \mathrm{K}\right), T$ is the absolute temperature, and $n_{0}$ is the ionic concentration of the bulk solution. Based on the formula, the thickness of EDL (i.e., the distance between soil particles) decreases with the increase of the ionic concentration of the bulk solution. Besides, the precipitated phase of the salt solution and the new substance produced 


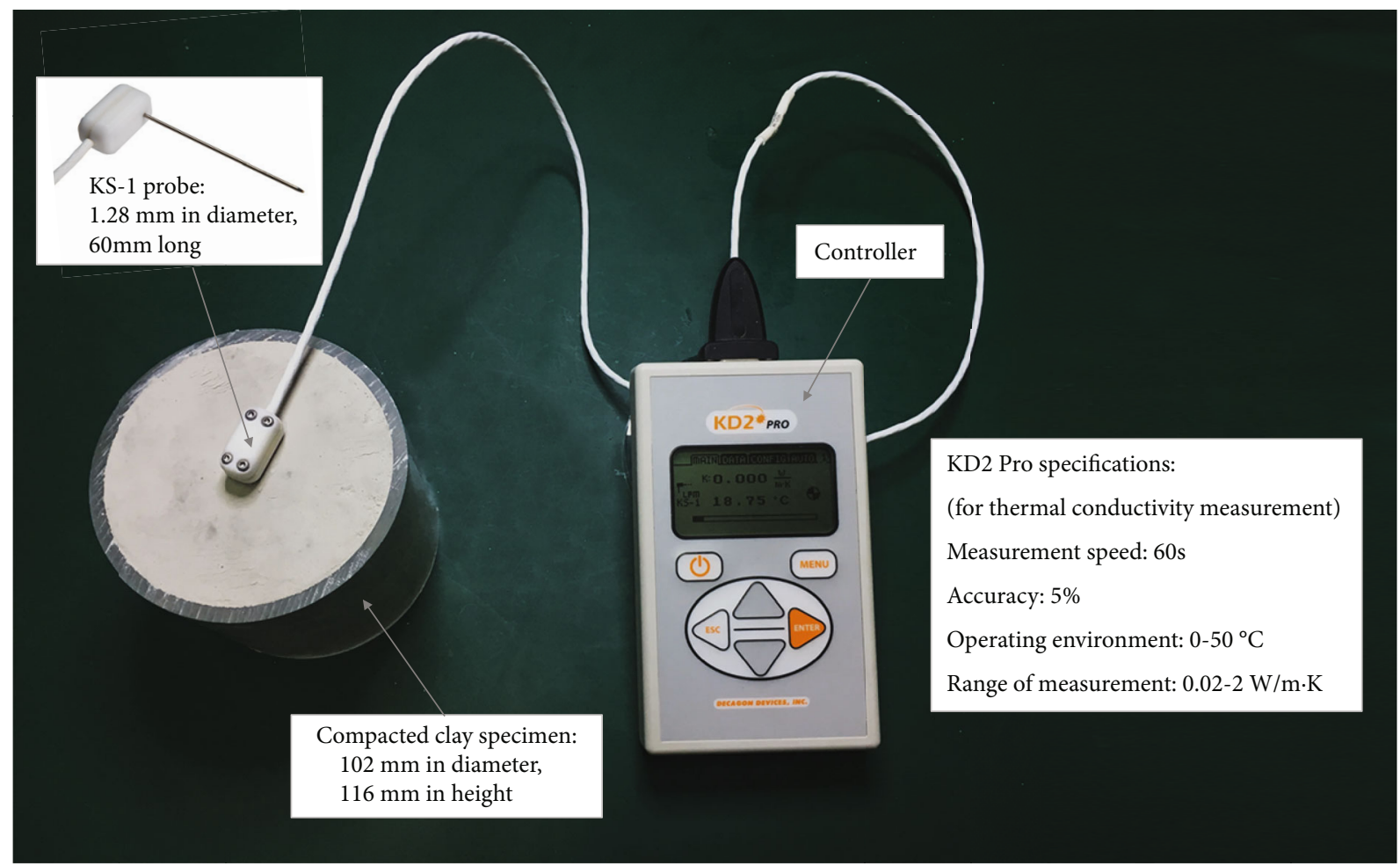

Figure 2: Measurement of thermal conductivity.

by chemical reaction of the soil colloid and salt act as "fillers" in the soil pore, causing the reduction of soil pore volumes; thus, the soil becomes denser. In addition, the hygroscopic properties of chloride salt enable a good performance of water maintenance in saline soil, making the soil particles easier to compact, ceteris paribus. Therefore, saline soils at higher salt contents generally have higher dry density and lower optimum moisture content.

3.1.2. Shear Strength. The relationship between salt concentrations and shear strength parameters of saline soil is illustrated in Figure 5. As the salt concentrations of the bulk solution increased, both the internal friction angle $\varphi\left({ }^{\circ}\right)$ and cohesion $c(\mathrm{kPa})$ fluctuated up and down but the overall trend eventually increased. This can also be explained by the theory of EDL. As previously described, with the increase of salt concentrations of the bulk solution, the thickness of EDL decreased. Moreover, salt will crystallize and act as a skeleton in soil pores when the salt concentrations of the pore fluid get saturated; therefore, both the surface roughness and contact area of soil particles increased accordingly, making the friction force between particles increase [32, 33]. As can be seen in Figures 5(a) and 5(c), for a constant concentration of salt solution, internal friction increased with increasing moisture content. The reason for this is that the higher moisture content means more salt solution was introduced to the soil; thus, the internal friction would have a slight increase (no more than $2^{\circ}$ ). Nevertheless, the internal friction did not show remarkable change for the pure water (salt concentration $=0 \mathrm{~mol} / \mathrm{kg}$ ). From Figures 5(b) and 5(d), it can be seen that in high salt concentrations $(4.5 \mathrm{~mol} / \mathrm{kg}$ and $6 \mathrm{~mol} / \mathrm{kg}$ for $\mathrm{NaCl} ; 3 \mathrm{~mol} / \mathrm{kg}, 4.5 \mathrm{~mol} / \mathrm{kg}$, and $6 \mathrm{~mol} / \mathrm{kg}$ for
$\mathrm{CaCl}_{2}$ ), the cohesion increased slightly after the moisture content surpassed $20 \%$. This is probably because the crystal salt and the bonds provided by the exchanged cations enhanced the cohesion of the soil [26], whereas for low soil salt content, the decrease of cohesion was dominated by water; viz., the water films between soil particles largely decreased the cohesion.

In addition, salt can increase the suction of unsaturated soils, causing the increase of shear strength [34]. Farouki [26] stated that the bonds provided by the exchanged cations can also contribute to the strength of clay. But the shear strengths of salt-treated soils were only increased about $5 \%$ as the $\mathrm{NaCl}$ or $\mathrm{CaCl}_{2}$ salt concentration increased from $0 \mathrm{~mol} / \mathrm{kg}$ to $6 \mathrm{~mol} / \mathrm{kg}$ (indicated in Figure 6). The reason for this is that the shear strength of soil is affected by several factors, such as the strength of soil particles, soil fabric, pore fluids, van der Waals force, electrostatic attraction and repulsion, suction, and chemical bond action [35-37]; the addition of salt solution may decrease the cohesion but increase the internal frictional angle of the soil; the complex physicalchemical reaction may contribute to the strength in some aspects but decay in others. Therefore, $\mathrm{NaCl}$ and $\mathrm{CaCl}_{2}$ only had limited effect on the shear strength of soil.

3.1.3. Compression Behaviors. The compression curves of saline soil are acquired with the help of a modified oedometric cell (see Figure 1), and test results are shown in Figure 7. The calculated coefficients of compressibility are given in Figure 8. The compression behavior is quite different between salt-affected and salt-unaffected soils under lower vertical stresses $(0 \mathrm{kPa} \sim 50 \mathrm{kPa})$ while the difference gradually disappeared under higher vertical stress $(50 \mathrm{kPa} \sim 250 \mathrm{kPa})$ 


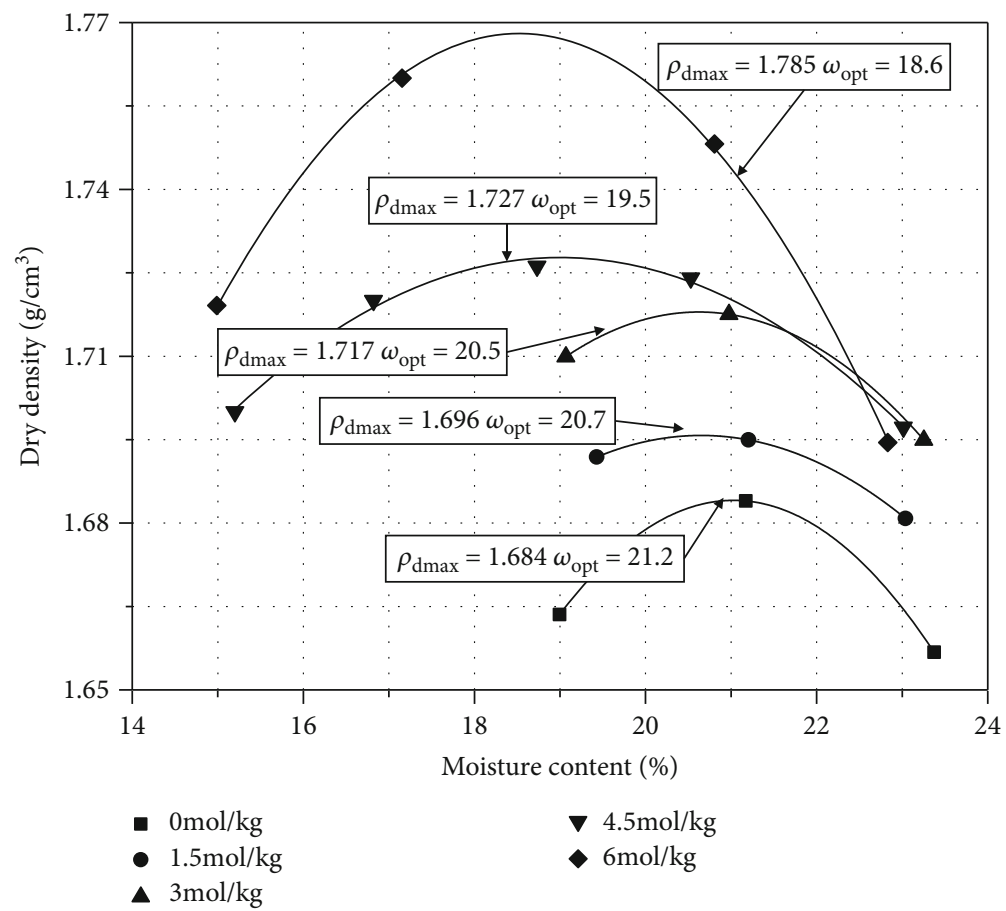

(a) $\mathrm{NaCl}$

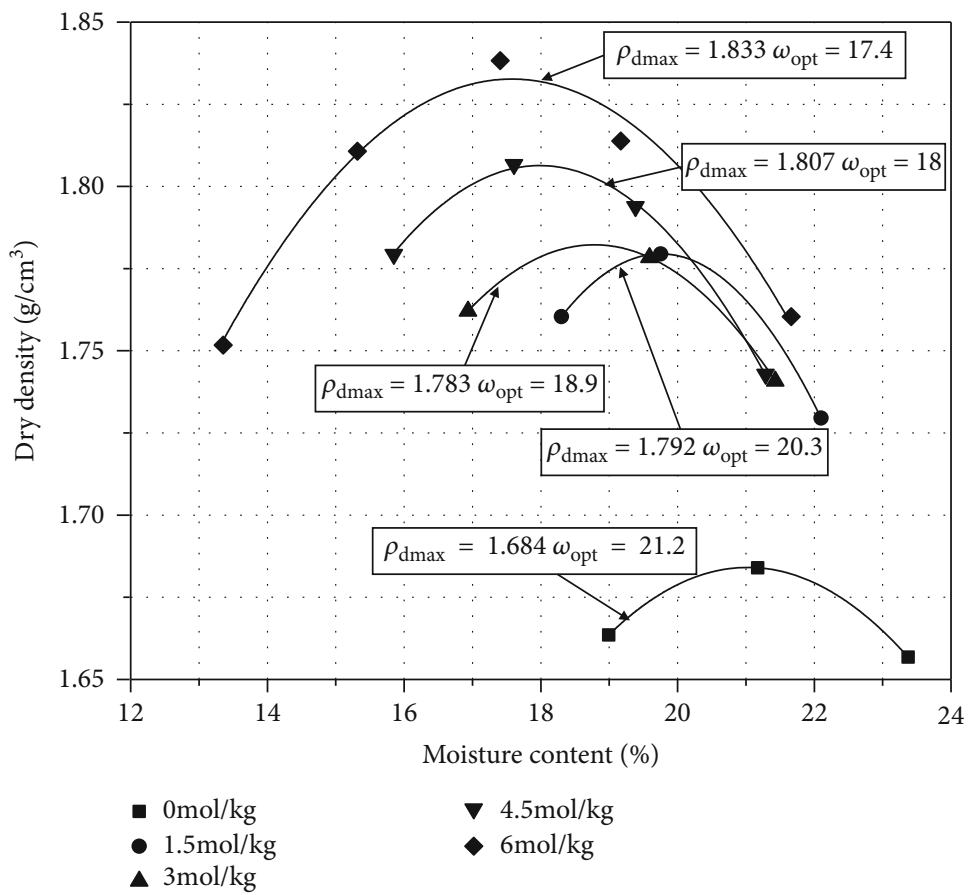

(b) $\mathrm{CaCl}_{2}$

FIgURE 3: The compaction curves of saline soil with different concentrations of (a) $\mathrm{NaCl}$ and (b) $\mathrm{CaCl}_{2}$ solutions (unit: $\mathrm{g} / \mathrm{cm}^{3}$ for $\rho_{\mathrm{dmax}}$, $\%$ for $\left.\omega_{\text {opt }}\right)$.

conditions. For untreated soils, the compression deformation is mainly caused by the reduction of pore space in soil and the elastic deformation of the soil structure; no (or slight) damage occurred between the connection of the soil skeleton under very low vertical stresses [38]. For salt-affected soils, however, the soil colloid is corroded by the salt before loading; the composition of the soil has changed and the connec- tion of the soil structure weakened or even lost. Therefore, the compression deformation of salt-affected soils under minor loads includes both the reduction of the pore volume and the compression caused by plastic deformation of the soil structure. Due to this reason, the compression behavior varied significantly between salt-affected and salt-unaffected soils (Figure 7). Nevertheless, elastic deformation and structure 


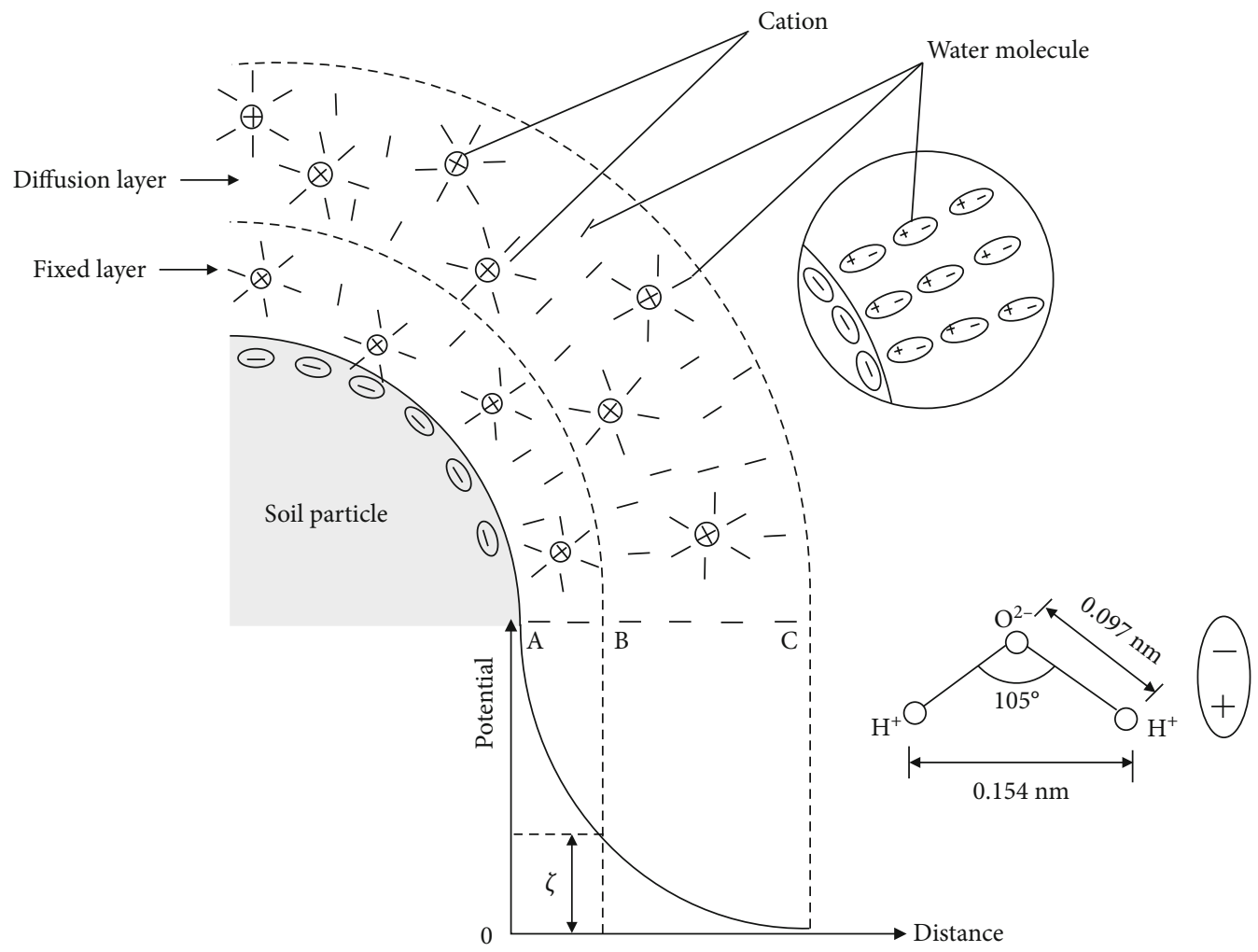

FIgUre 4: Electric double layer (EDL) of soil particles.

damage occurred in both types of soil under high load conditions; hence, both salt-affected and salt-unaffected soils exhibited similar compression results under high load conditions. The test results also revealed that the slope of compression curves becomes steeper with the increase of salt concentrations and the compressibility of the $\mathrm{CaCl}_{2}$-affected soil is always larger than that of the $\mathrm{NaCl}$-affected soil. The main cause is that the higher salt concentration and greater ion exchange capacity of higher valence ions might damage the soil colloid and destroy the soil structure; thus, the soil exhibited greater compressibility.

3.1.4. Velocity-Stress Behavior. The shear wave velocity of saline soil was tested while conducting the compression tests. Figure 9 shows the typical received signal of the bender element during loading and unloading, from which the first arrival time (at the arrowhead) can be obtained; with the known tip-to-tip distance (travel distance), the shear wave velocity can be calculated. Figure 10 presents the shear wave velocity-stress behavior of all the salt-treated specimens. The shear wave velocity in the hypersaline condition is found to be higher than that under low-salt conditions, and such difference is even pronounced under higher applied vertical stresses (shear wave velocity rose by $50.06 \%$ to $82.93 \%$ under $12.5 \mathrm{kPa}$ to $250 \mathrm{kPa}$ for $\mathrm{NaCl}$-treated soil and $39.49 \%$ to $51.52 \%$ for $\mathrm{CaCl}_{2}$-treated soil). As discussed previously, the precipitated phase of the salt solution and new substance produced by the chemical reaction of the soil colloid and salt act as "fillers" in the soil pore; thus, the pore volumes decrease; salt can also make the soil particles become closer by contracting the EDL, causing the reduction of soil pore volumes; in addition, higher applied vertical stress make the soil samples denser, in which the shear wave propagates faster [30]. The shear wave velocity of $\mathrm{NaCl}$-affected kaolin was found slightly higher than the velocity of $\mathrm{CaCl}_{2}$-affected kaolin under the same stress and salt concentration. Higher valence ions (i.e., $\mathrm{Ca}^{2+}$ ) have higher cation exchange capacity and, thus, bring more damage to the soil colloid and soil structure. The shear wave propagation hence is affected when the soil skeleton is damaged and disordered.

3.2. Thermal Conductivity of Saline Soil. Thermal conductivities of soil samples with different moisture contents and salt concentrations are plotted in Figure 11. The thermal conductivity decreased by $0.121 \mathrm{~W} \mathrm{~m}^{-1} \mathrm{~K}^{-1}$ for NaCl-treated soil and $0.129 \mathrm{~W} \mathrm{~m}^{-1} \mathrm{~K}^{-1}$ for $\mathrm{CaCl}_{2}$-treated soil on average when the salt concentration increased from $0 \mathrm{~mol} / \mathrm{kg}$ to $6 \mathrm{~mol} / \mathrm{kg}$. The thermal conductivity of $\mathrm{CaCl}_{2}$-treated soil is slightly lower than that of $\mathrm{NaCl}$-treated soil. Moreover, the test results showed that thermal conductivity decreased with the increase of moisture content, which contradicted with the literature findings [18, 20, 26, 38]. According to Wiener [39] and Johansen [18], the thermal conductivity of porous media, which include solid, liquid, and gas, can be calculated by the geometric average (GA) method. It is noteworthy that with the increase in salt concentration of the soil solution, the thermal conductivity of the soil air and soil solution will decline [25, $40-42$ ]; viz., the thermal conductivity of both the liquid and gas phases decreases with the increase of the salt content; therefore, the thermal conductivity of the soil decreases. In addition, the bonds between the exchanged cations were expected to affect the heat transfer process among soil particles 


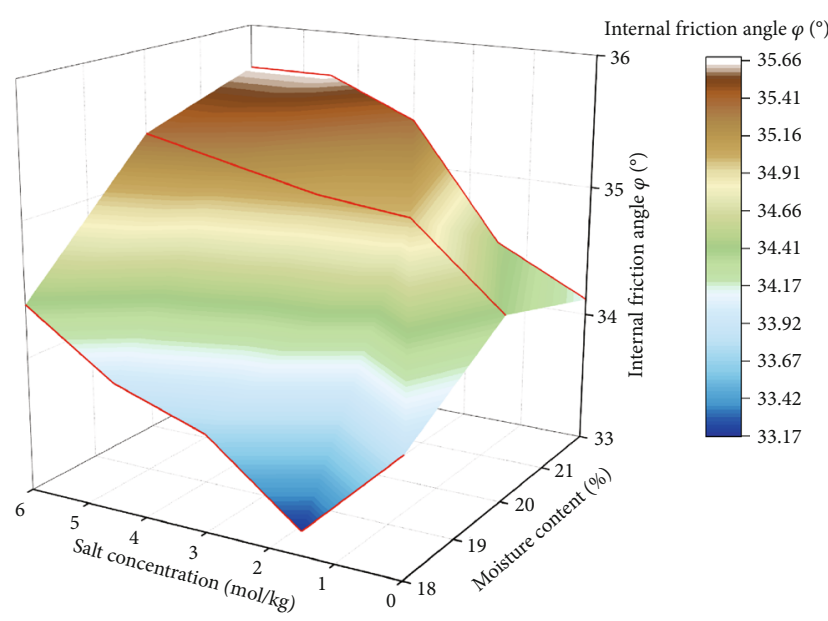

(a) $\mathrm{NaCl}-\varphi\left({ }^{\circ}\right)$

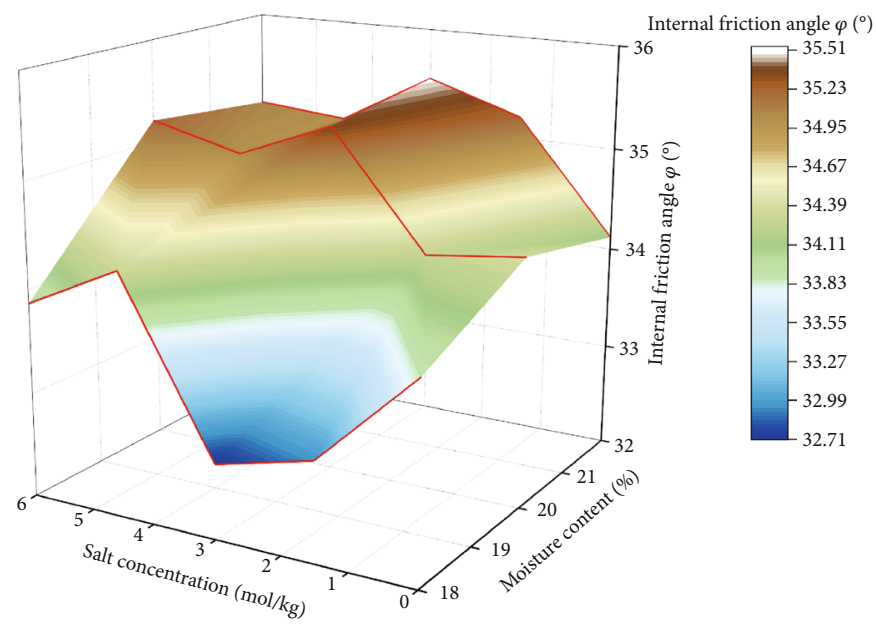

(c) $\mathrm{CaCl}_{2}-\varphi\left(^{\circ}\right)$

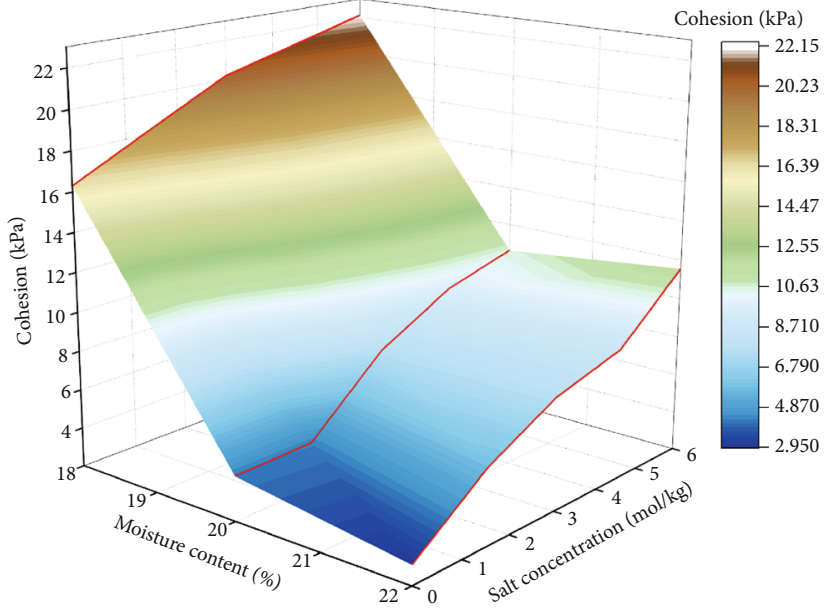

(b) $\mathrm{NaCl}-c(\mathrm{kPa})$

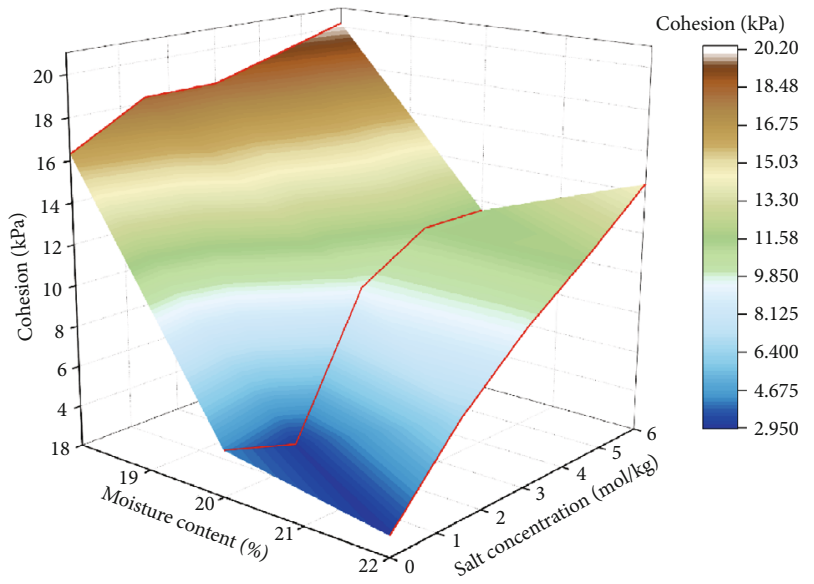

(d) $\mathrm{CaCl}_{2}-c(\mathrm{kPa})$

FIGURE 5: Effect of salt concentrations of bulk solution on shear strength parameters.

$[26,43,44]$. For soils with a significant amount of clay, flocculation and aggregation may be strongly influenced by the interactions of clay particles with salt ions [25]. This statement is verified by the SEM results. As seen in Figure 12, salt can promote the formation of soil aggregation and the size of soil aggregates increases with the addition of salt. The chemical bond action and the crystalline salt can increase the interface adhesion of soil particles, together with the effect of crystalline swelling, macroscopic swelling, and overall particle-particle interaction, changing a lot the microstructure of the soil in the hypersaline environment in contrast to the unaffected soil. Farouki [26] speculated that the less ordered the structure of the clay (i.e., more flocculated), the lower the thermal conductivity. In recognition of those evidences, we can conclude that the higher the content of salt in the sample, the lower the thermal conductivity it would have.

\section{Model Study of Mechanical and Thermal Properties of Saline Soil}

4.1. An Elastic Shear Modulus $\left(G_{0}\right)$ Model for Saline Soil. The $G_{0}$ of soil is an important parameter to predict the service- ability of many earth structures in geoenergy and geoenvironmental engineering $[45,46]$. There are many models reported in the literature for predicting the $G_{0}$ of soils. Mancuso et al. [47] and $\mathrm{Ng}$ and Yung [48] proposed two models which assumed that $G_{0}$ is a function of net stress, suction, and void ratio. Moreover, a number of studies incorporated the degree of saturation $\left(S_{r}\right)$ in the model to account for the unsaturated conditions [49-53]. By using the suction stressbased effective stress principle, Dong et al. [54] and Dong and $\mathrm{Lu}$ [55] developed a $G_{0}$ model with three model parameters. It should be pointed out that all these models require at least three parameters and the calibration of the model parameters requires extensive time-consuming laboratory tests. Nevertheless, no $G_{0}$ model with regard to the saline soil has been reported.

In 1966, Hardin and Black [56] demonstrated the influence of the void ratio $(e)$ and mean effective stress $\left(p^{\prime}\right)$ on the $G_{0}$ through an empirical equation:

$$
G_{0}=A \cdot F(e) \cdot\left(P^{\prime}\right)^{m}
$$




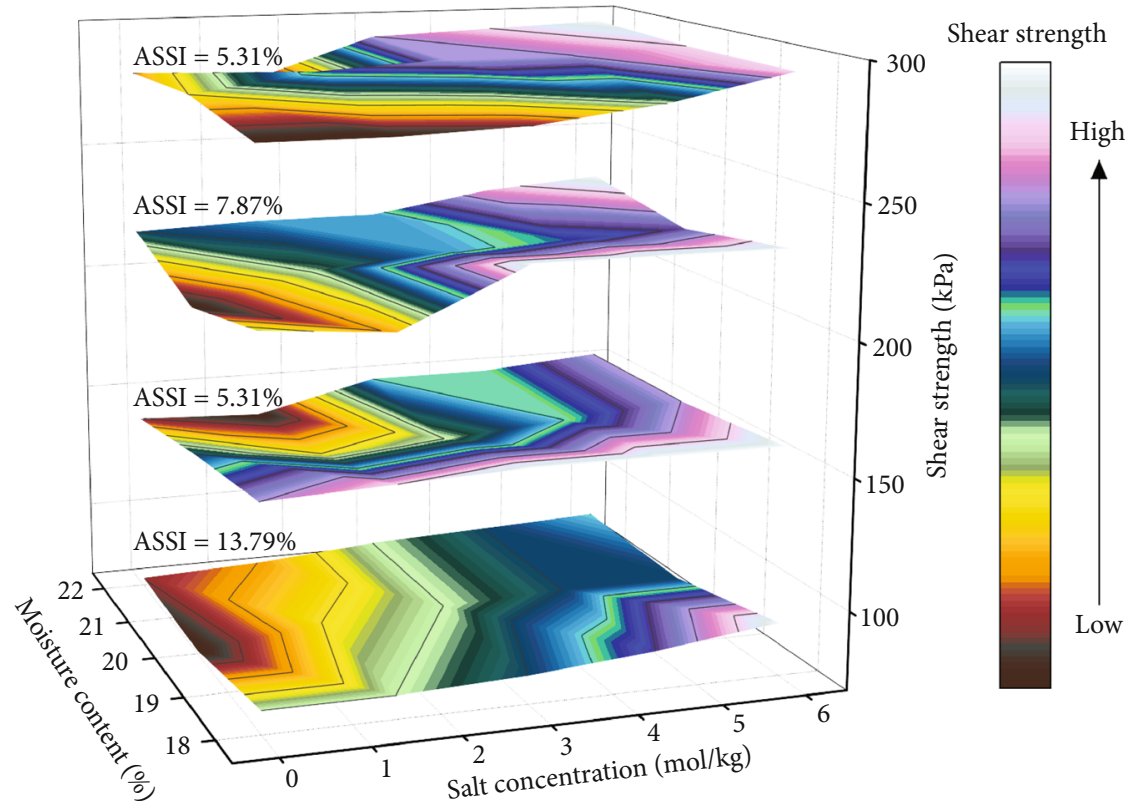

(a) $\mathrm{NaCl}$

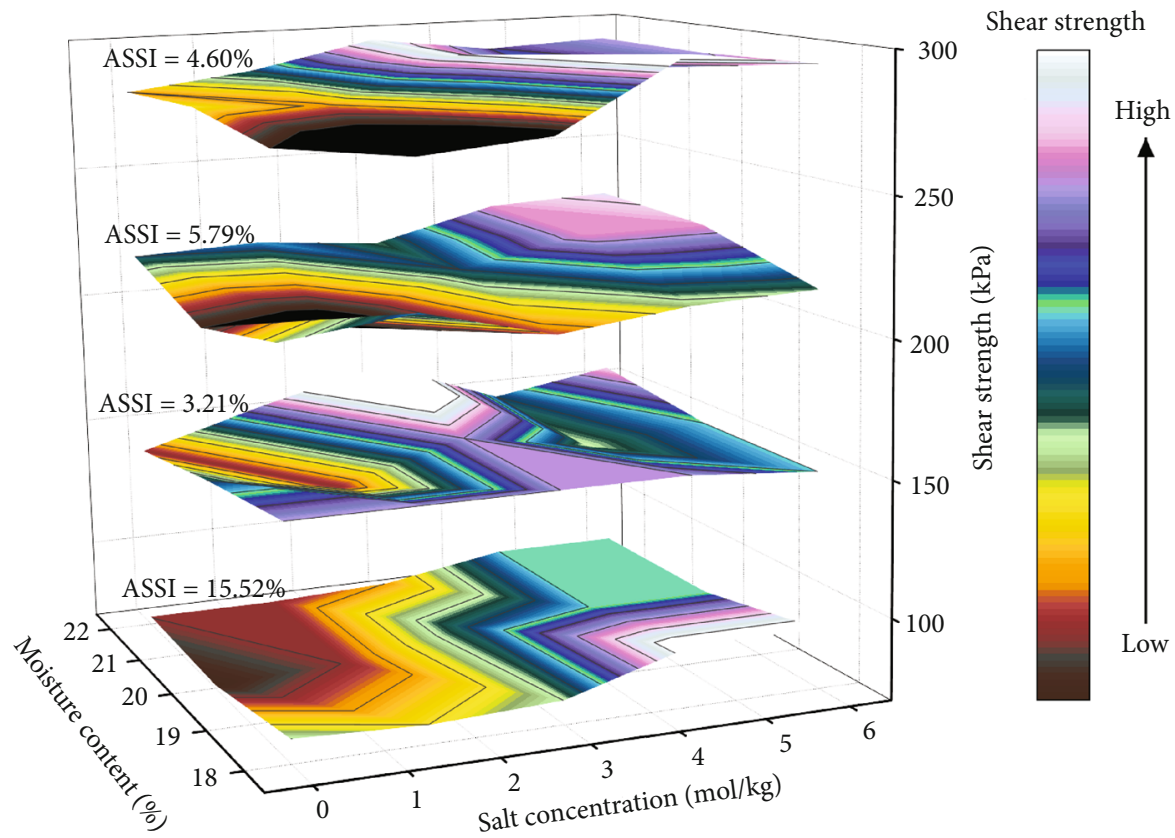

(b) $\mathrm{CaCl}_{2}$

FIGURE 6: The relationship between shear strength and salt concentrations under different moisture contents and different vertical stresses (ASSI: average shear strength increment with the salt concentration increasing from $0 \mathrm{~mol} / \mathrm{kg}$ to $6 \mathrm{~mol} / \mathrm{kg}$ under the same vertical stress).

where $F(e)$ is a function of the void ratio and $A$ and $m$ are material constants. This classic equation is also known as the Hardin equation, and it has been widely used to estimate the $G_{0}$ of different soils, including sand, silt, and clay. For the $F(e)$, various formulations have been reported in the literature. Hardin and Black [56] proposed $F(e)=\left(e_{g}-e\right)^{2} /(1+e)$, where $e_{g}$ was proposed for sands of different angularity. Shibuya et al. [57] introduced a simplified void ratio function $F(e)=(1+e)^{a}$, where the coefficient $a$ is equal to -2.4 for clay based on the in situ seismic survey and laboratory bender element tests. According to the previous analysis in this study, salt can affect the microstructure of soils, making the void ratio variable. Therefore, the soil salt content should be incorporated in $F(e)$. Substituting the concentration of salt solution $(\theta)$ and moisture content $(\omega)$ into $F(e)$, the following equation can be obtained:

$$
F(e)=(1+e)^{(M \cdot \theta \cdot \omega) / 100},
$$




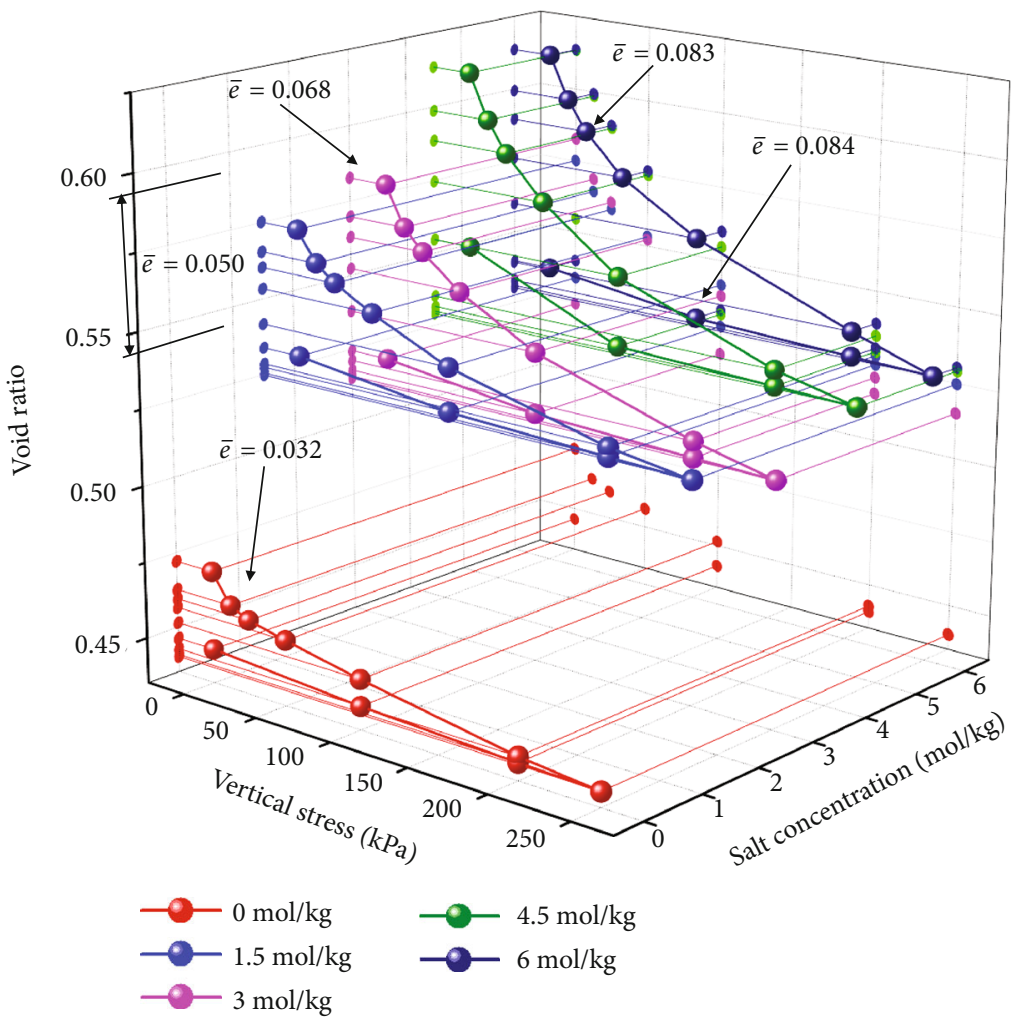

(a) $\mathrm{NaCl}$

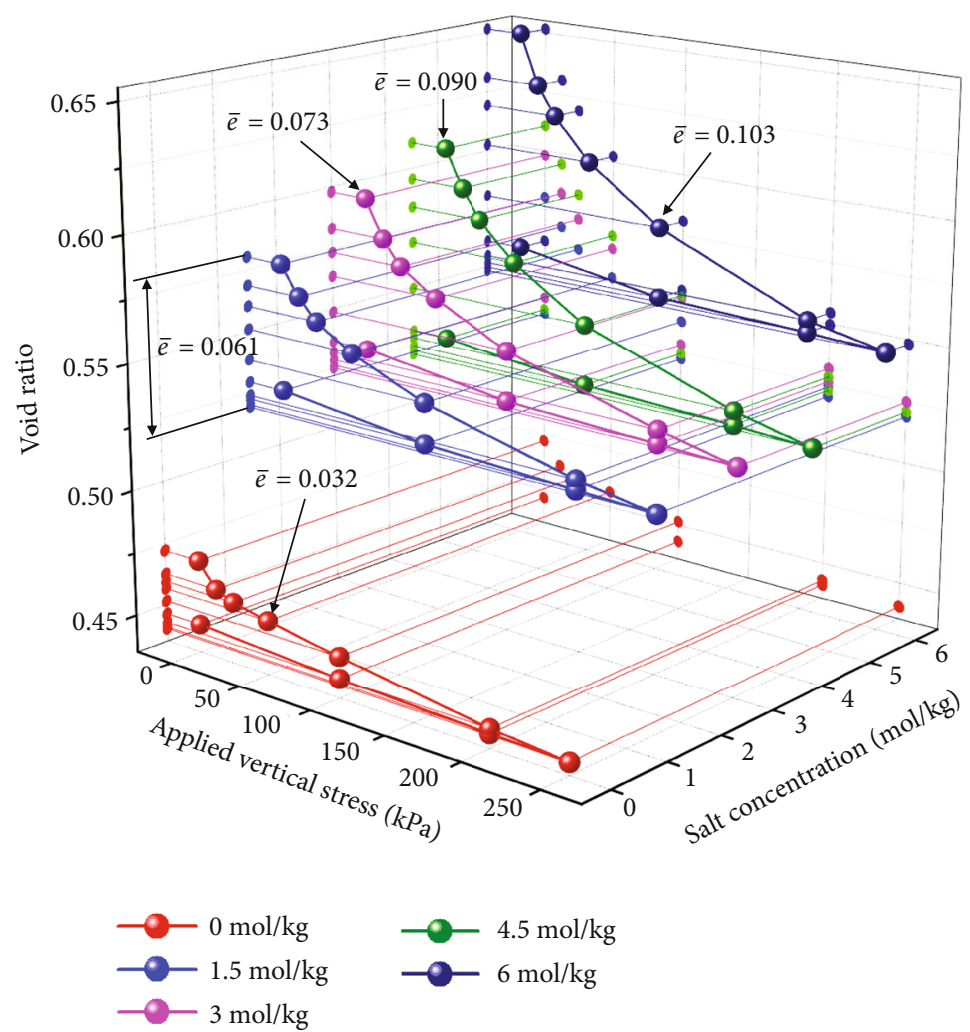

(b) $\mathrm{CaCl}_{2}$

Figure 7: Compression curves of different saline soils ( $\bar{e}$ : maximum change of void ratio during loading). 


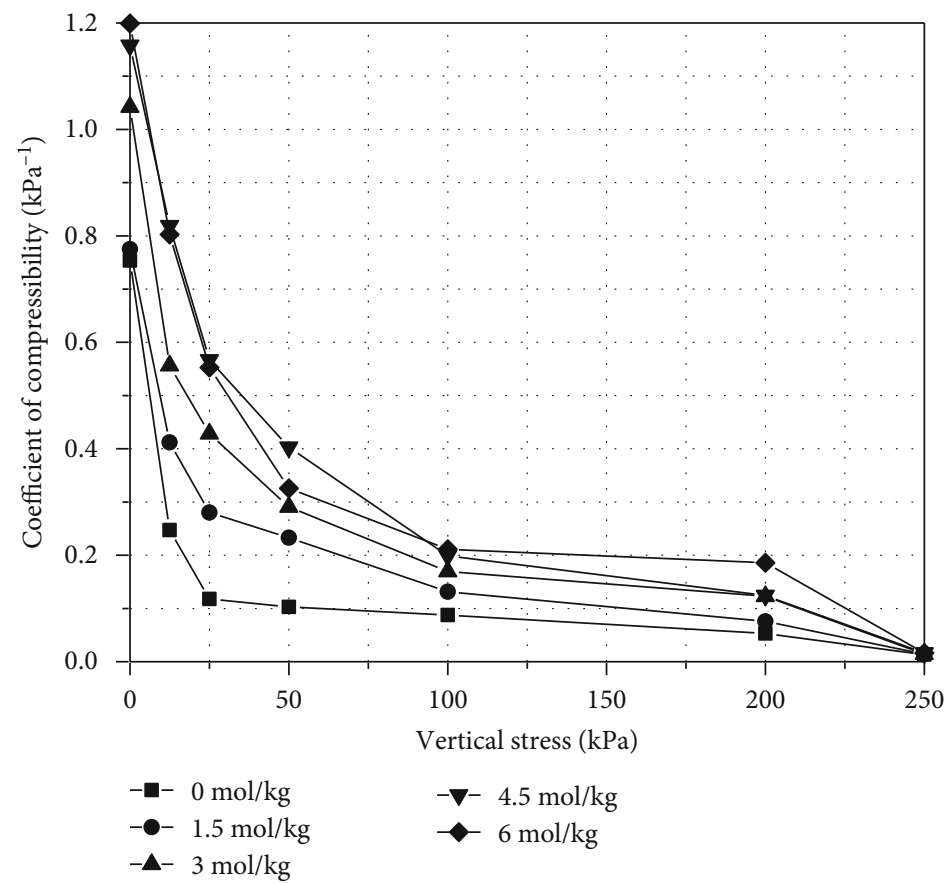

(a) $\mathrm{NaCl}$

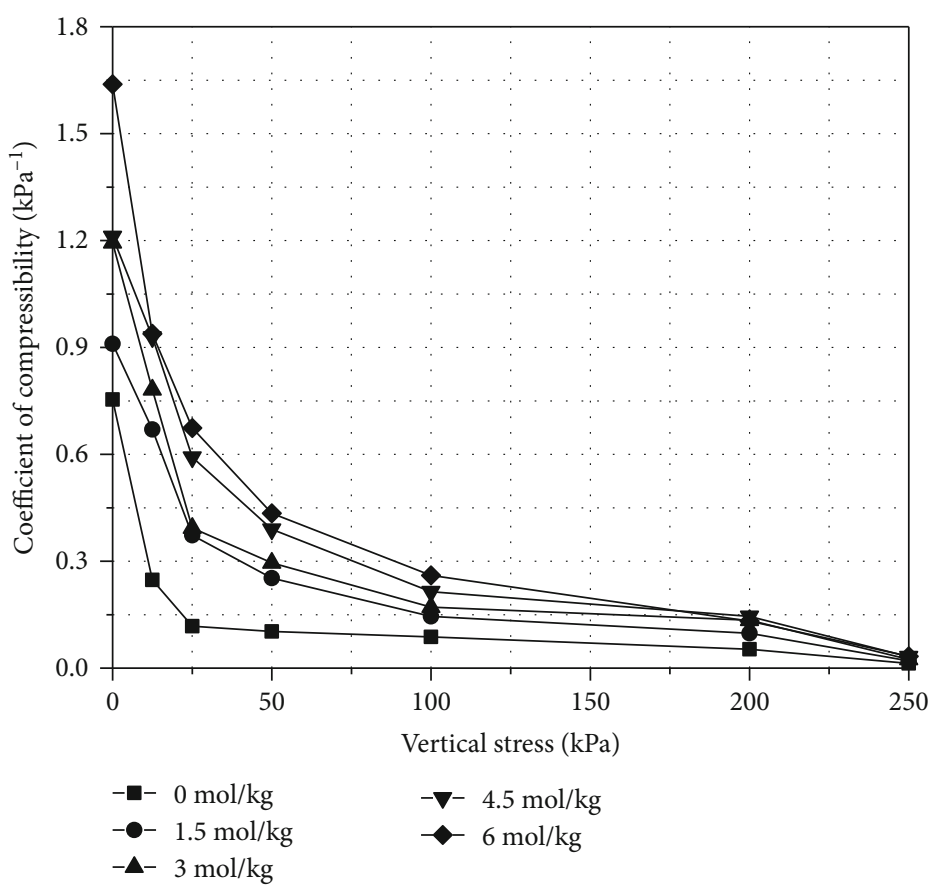

(b) $\mathrm{CaCl}_{2}$

Figure 8: Coefficient of compressibility of saline soil with (a) $\mathrm{NaCl}$ and (b) $\mathrm{CaCl}_{2}$ solutions.

where $M(\mathrm{~g} / \mathrm{mol})$ is the molar mass of added salt. By conducting extensive laboratory experiments, McDowell and Bolton [58] found that $G_{0}$ varied with $P^{\prime}$ and $\left(P^{\prime}\right)^{m}$ following the Hertz contact theory, and they suggested that $m=0.5$. In addition, the Hardin equation was proposed for saturated soils, whereas the soils are often unsaturated in the field. Hence, following the instructions of $\mathrm{Ng}$ and Yung [48], the reference pressure $P_{\text {ref }}$ was introduced to the Hardin equa- tion for normalizing $P^{\prime}$ and is assumed to be the atmospheric pressure $(101 \mathrm{kPa})$ in the subsequent calculations. Concluding all the above considerations into the Hardin equation, it can be drawn that

$$
G_{0}=A \cdot(1+e)^{(M \cdot \theta \cdot \omega) / 100} \cdot\left(\frac{P^{\prime}}{P_{\text {ref }}}\right)^{0.5} .
$$




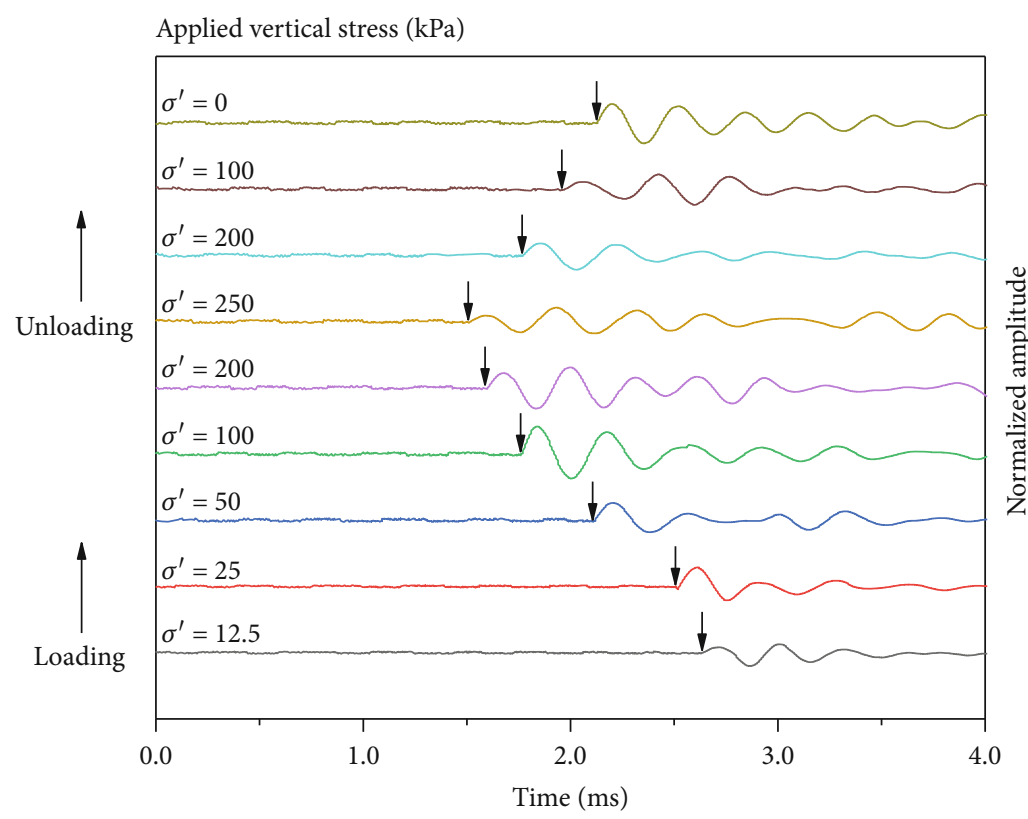

FIgURE 9: The typical received signal of a bender element during loading and unloading.

This model thus can describe the $G_{0}$ of unsaturated saline soils, requiring only one parameter $A$.

Figure 13 shows the performance of this model (equation (4)). It can be seen that the calculated values have a high correlation with the measured data. It should be noted that the values of exponential in $F(e)$, i.e., $(M \cdot \theta \cdot \omega) / 100$, vary from 0 to 1.177 in this study, which are greater than the values of -2.4 to -3 in most other studies $[46,59]$. The soils are denser in salinity conditions; therefore, the addition of salt will decrease the void ratio and make the soil have greater $G_{0}$. If the exponential of $F(e)$ ranges from -2.4 to -3 , the model may underestimate the $G_{0}$ of saline soil.

4.2. Thermal Conductivity Model of Saline Soils. Several researchers have attempted to model the thermal conductivity $(K)$ of soils [18, 20, 23, 41, 60-68]. DeVries [23] proposed a thermal conductivity model derived from Maxwell's equations. The weighted average thermal conductivity of each phase of the soil matrix was taken into account for the overall thermal conductivity of soil. Kersten [69] proposed an empirical relationship between thermal conductivity and moisture content and dry density. Johansen [18] proposed an equation to predict the thermal conductivity of dry soils and first presented the "normalize thermal conductivity $\left(k_{\mathrm{r}}\right)$ " concept. Côté and Konrad [66] proposed a more generalized $k_{\mathrm{r}}-S_{\mathrm{r}}$ relationship to develop a soil thermal conductivity model. Lu et al. [67] proposed a new $k_{\mathrm{r}}-S_{\mathrm{r}}$ relationship for establishing the thermal conductivity model. The Chen model [70] was developed from a series of thermal conductivity measurements of quartz sands. More details of these models are presented in the review works of Dong et al. [19] and Zhang and Wang [44]. As per the literature survey, most of the thermal conductivity models consider moisture content, dry density, and soil mineral components as the influencing factors of soil thermal conductivity. A few researchers, however, focused on the effect of salt on thermal conductivity, and there is even no available model relevant to saline soils. Therefore, by taking into account the soil salt content, a modified thermal conductivity model was proposed. The model development is shown below.

According to the Maxwell equation, DeVries [23] proposed a method that uses the weighted average of the thermal conductivity value of each soil constituent. The model is given as follows:

$$
K=\frac{\sum_{i=0}^{N} K_{i} x_{i} k_{i}}{\sum_{i=0}^{N} K_{i} x_{i}}
$$

where $k_{i}$ is the thermal conductivity of each constituent $\left(\mathrm{W} \mathrm{m}^{-1} \mathrm{~K}^{-1}\right), x_{i}$ is the volume fraction of each constituent, and $K_{i}$ is the ratio of the average thermal gradient of each constituent to that of continuous medium in soils, which is as follows:

$$
K_{i}=\frac{\overline{(d T / d z)_{1}}}{\overline{(d T / d z)_{0}}} .
$$

Since $K_{i}$ is affected by some factors, such as $k_{1} / k_{0}$ (i.e., the ratio of the thermal conductivity of one soil constituent to that of a continuous medium in soils), particle size, shape, and relative position, DeVries [23] presented an equation to calculate $K_{i}$ as follows:

$$
K_{i}=\frac{1}{3} \sum_{a, b, c,}\left[1+\left(\frac{k_{i}}{k_{0}}-1\right) g_{a}\right]^{-1},
$$

where $g_{a}, g_{b}$, and $g_{c}$ are the grain shape coefficients and usually taken as $1 / 3$ for spherical soil particles. DeVries [23] furthered that by assuming $g_{a}=g_{b}$, equation (7) still agreed well with experimental data. 

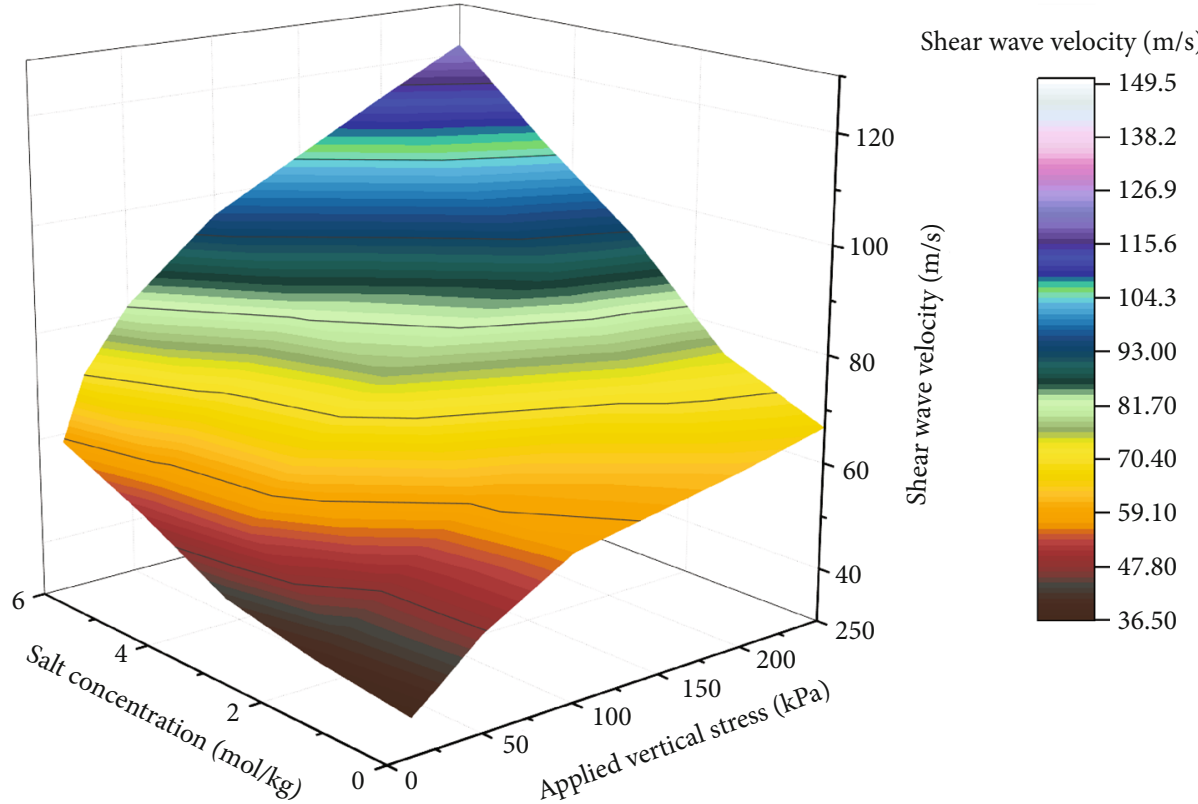

(a) $\mathrm{NaCl}$

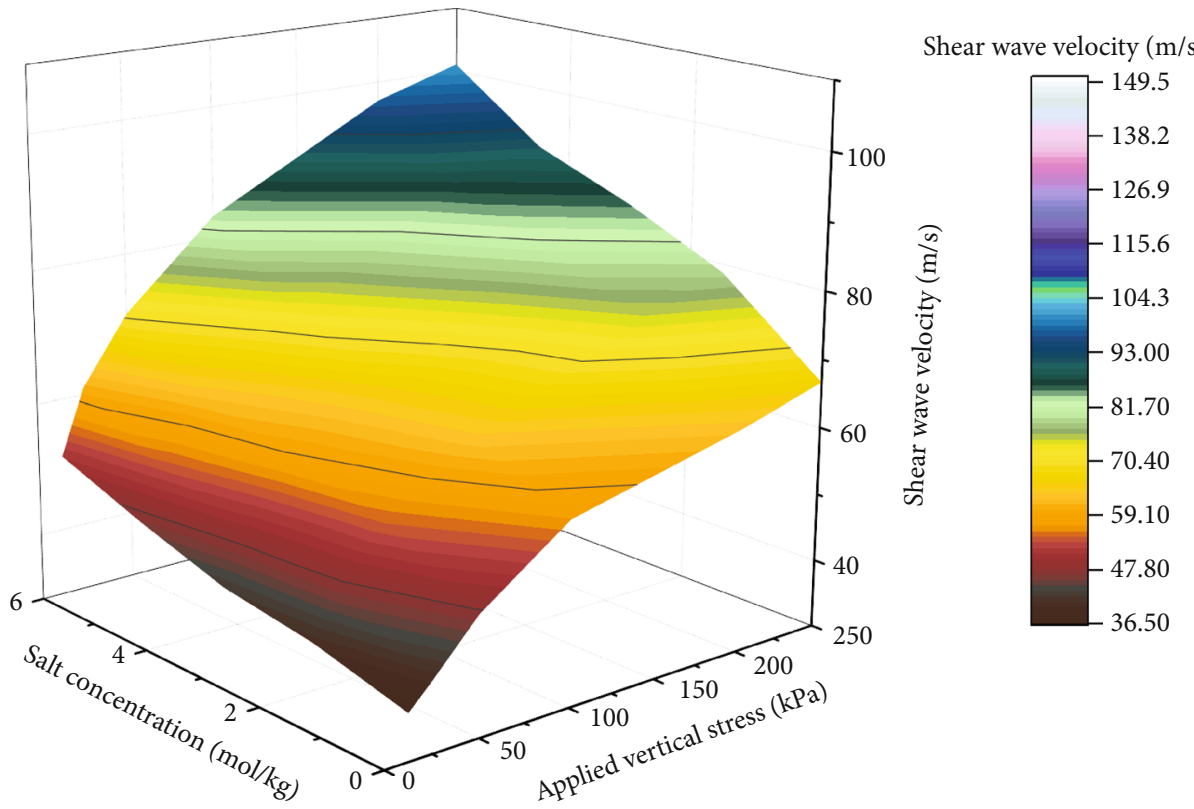

(b) $\mathrm{CaCl}_{2}$

FIGURE 10: Shear wave velocity-stress behavior of saline soils.

For unsaturated soils, solid particles and air are assumed to be two components immersed in the continuous medium: water. This assumption applies when the volumetric water fraction is above a certain minimum limit so that water can be considered as continuous. For fine-grained soils, this limit is $V_{w} / V=0.05$ to 0.10 [64]. The thermal conductivity of such soils is expressed as

$$
K=\frac{\left(V_{w} / V\right) K_{w}+F_{a}\left(V_{a} / V\right) K_{a}+F_{s}\left(V_{s} / V\right) K_{s}}{\left(V_{w} / V\right)+F_{a}\left(V_{a} / V\right)+F_{s}\left(V_{s} / V\right)},
$$

where $F_{s}$ and $F_{a}$ are the weighing factors related to soil particles and air pores, respectively.

The effect of salt on heat flow through the soil air should also be considered for the thermal conductivity of soil. Air is related to the latent heat transport from water vapor movement $\left(K_{v}\right)$, which varies with salt concentration. According to DeVries [23], from saturation to field capacity, the thermal conductivity of soil air can be calculated by $K_{a}+K_{v}$; the value of $K_{v}$ may be obtained as the product of the relative humidity $h$ and the thermal conductivity of saturated air $K_{v s}$. And the thermal conductivity of a gas-filled pore can be linearly 


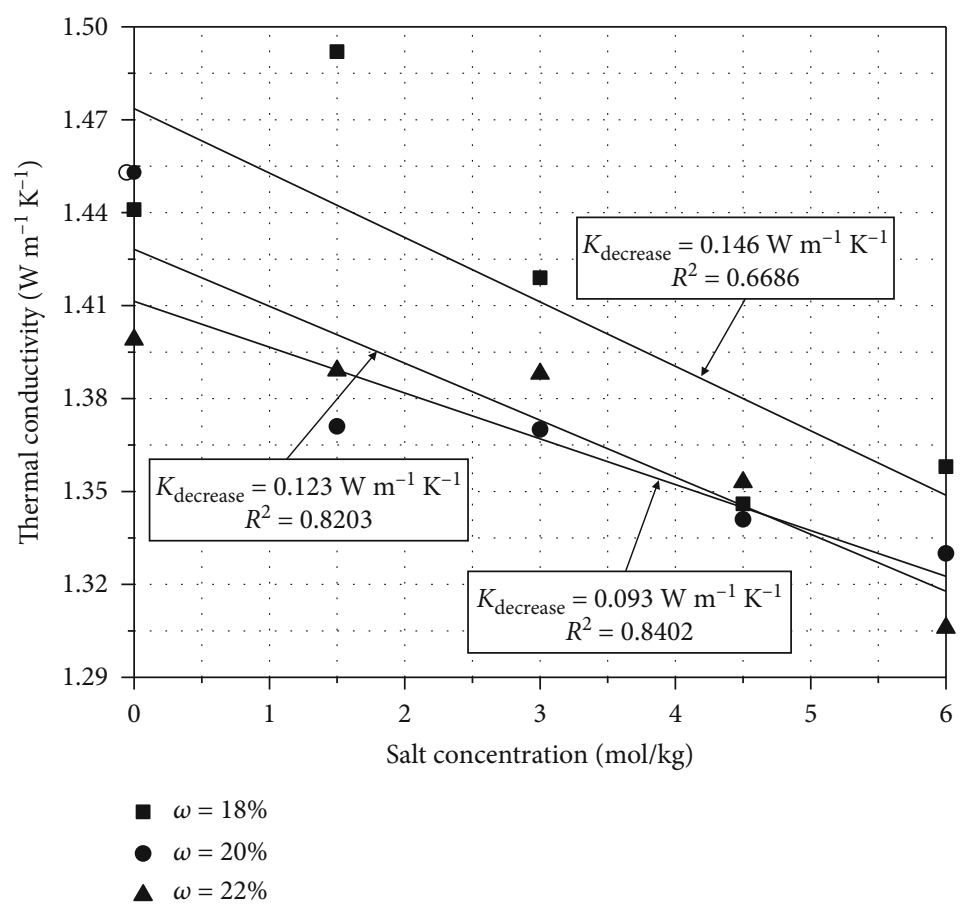

(a) Thermal conductivities of $\mathrm{NaCl}$-affected soil

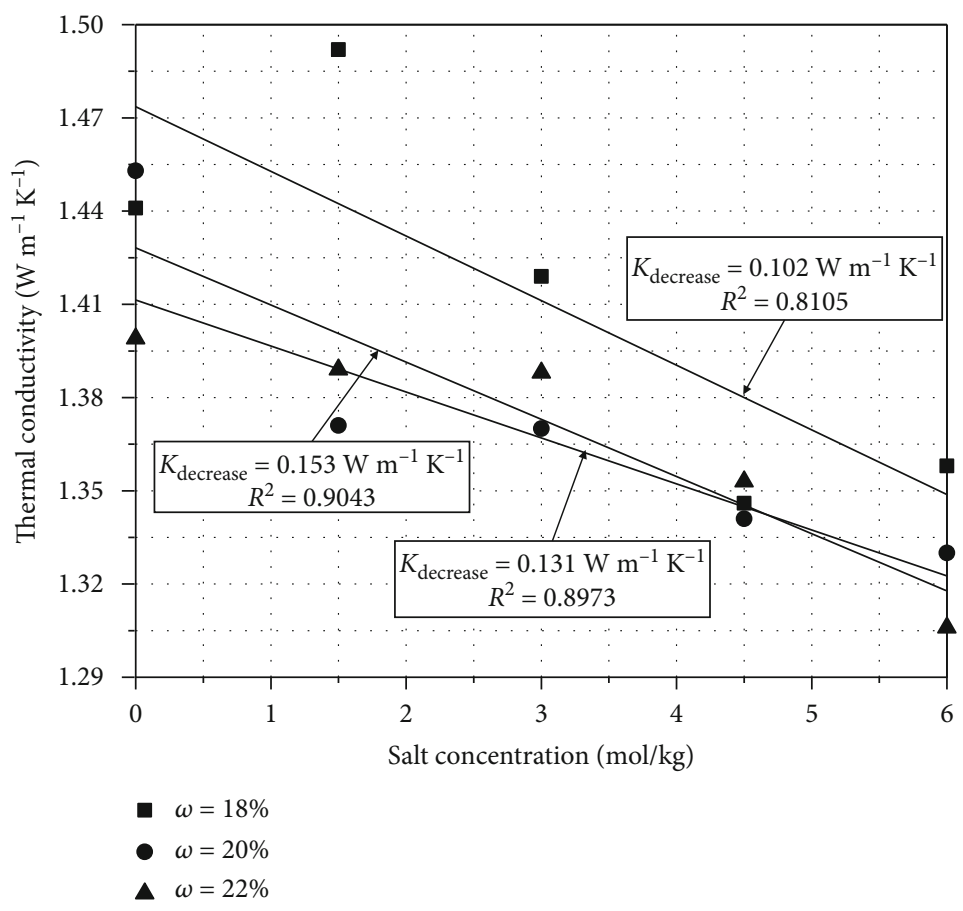

(b) Thermal conductivities of $\mathrm{CaCl}_{2}$-affected soil

FIGURE 11: Thermal conductivities of saline soil ( $K_{\text {decrease }}$ : average decrease of thermal conductivity with the salt concentration increased from $0 \mathrm{~mol} / \mathrm{kg}$ to $6 \mathrm{~mol} / \mathrm{kg})$.

interpolated from $K_{a}+h K_{v s}$ at field capacity to $K_{a}$ at zero water content. As the salt concentration in the soil solution increases, both $h$ and the magnitude of $K_{v}$ decrease.

Moreover, it is affirmative that salts could have an impact on the soil structure. Particle shape and orientation, the essence of the shape factor, change with increased concentra- tion of salt from a combination of aggregation, crystalline swelling, macroscopic swelling, and overall particle-particle interaction. Thus, the salt-induced microstructural changes have the most direct influence on shape factors of soil particles, which correspond to the weighing factors $F_{s}$ of soil particles. To evaluate the influence of soil salt content, the molar 


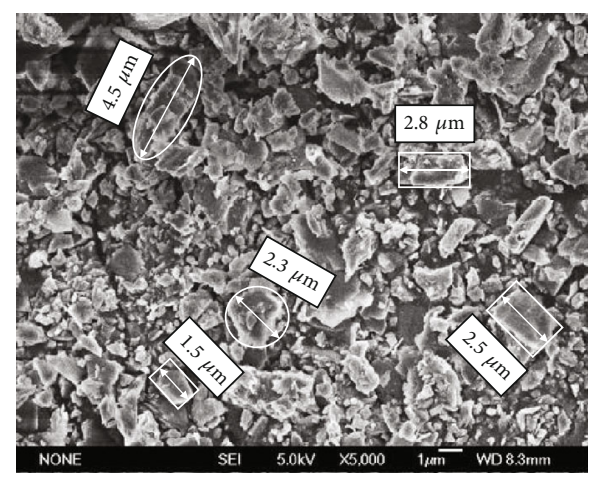

(a) Pure kaolin clay $(0 \mathrm{~mol} / \mathrm{kg})$

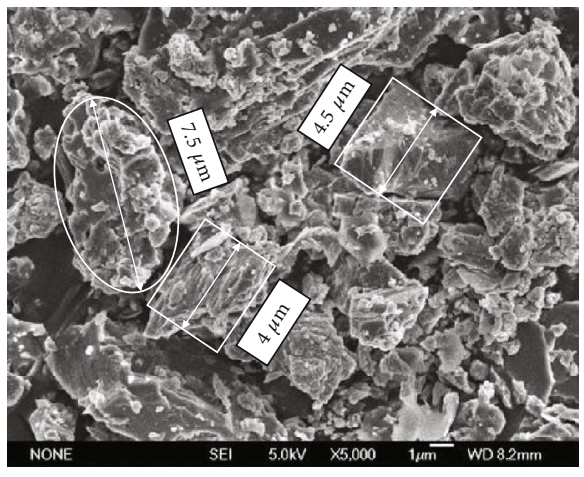

(b) $1.5 \mathrm{~mol} / \mathrm{kg} \mathrm{NaCl}$

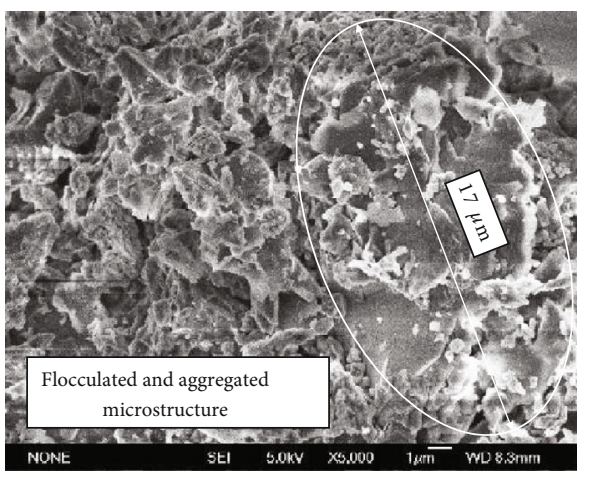

(d) $3 \mathrm{~mol} / \mathrm{kg} \mathrm{NaCl}$

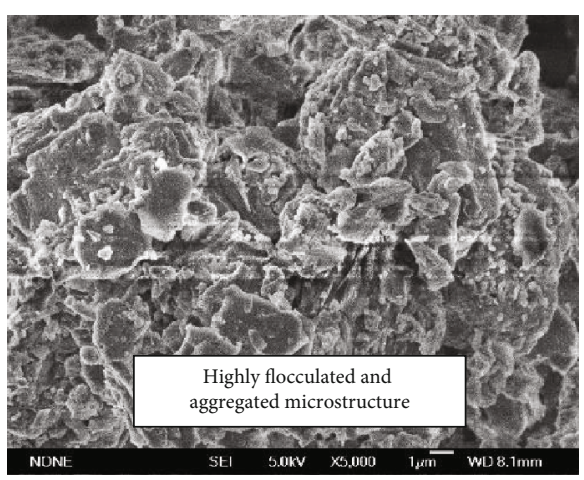

(f) $6 \mathrm{~mol} / \mathrm{kg} \mathrm{NaCl}$

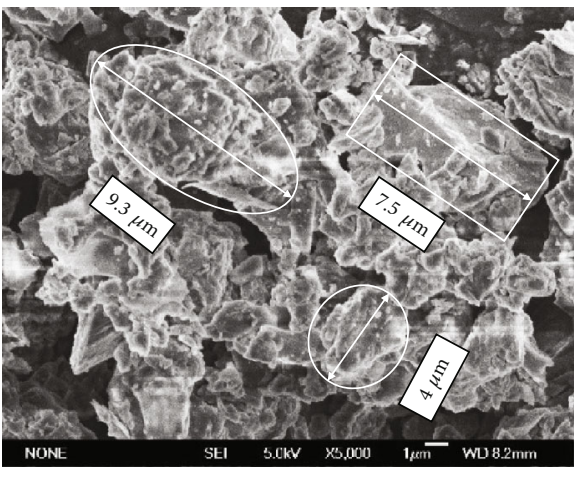

(c) $1.5 \mathrm{~mol} / \mathrm{kg} \mathrm{CaCl}_{2}$

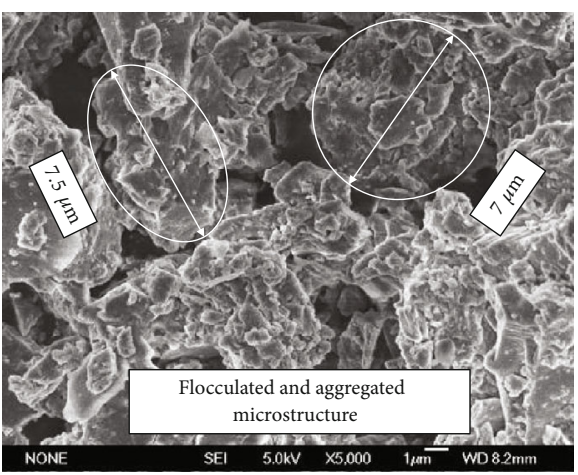

(e) $3 \mathrm{~mol} / \mathrm{kg} \mathrm{CaCl}{ }_{2}$

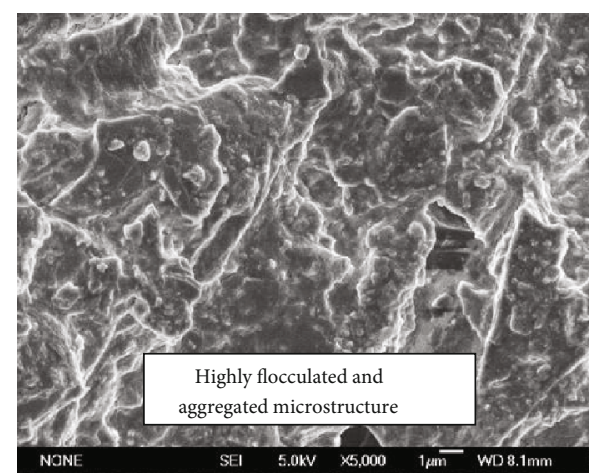

(g) $6 \mathrm{~mol} / \mathrm{kg} \mathrm{CaCl}$

FIGURE 12: Scanning electron micrographs of kaolin clay with different salt concentrations of the bulk solution $(\times 5000)$. 


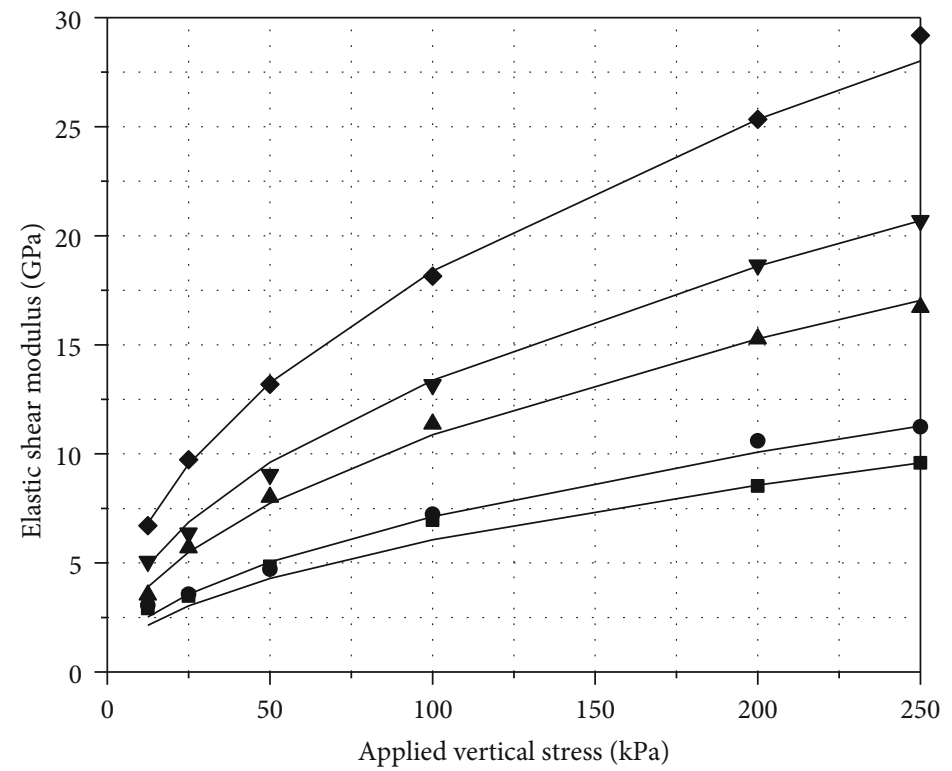

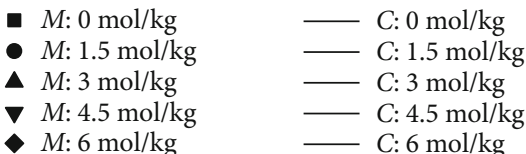

(a) $\mathrm{NaCl}$

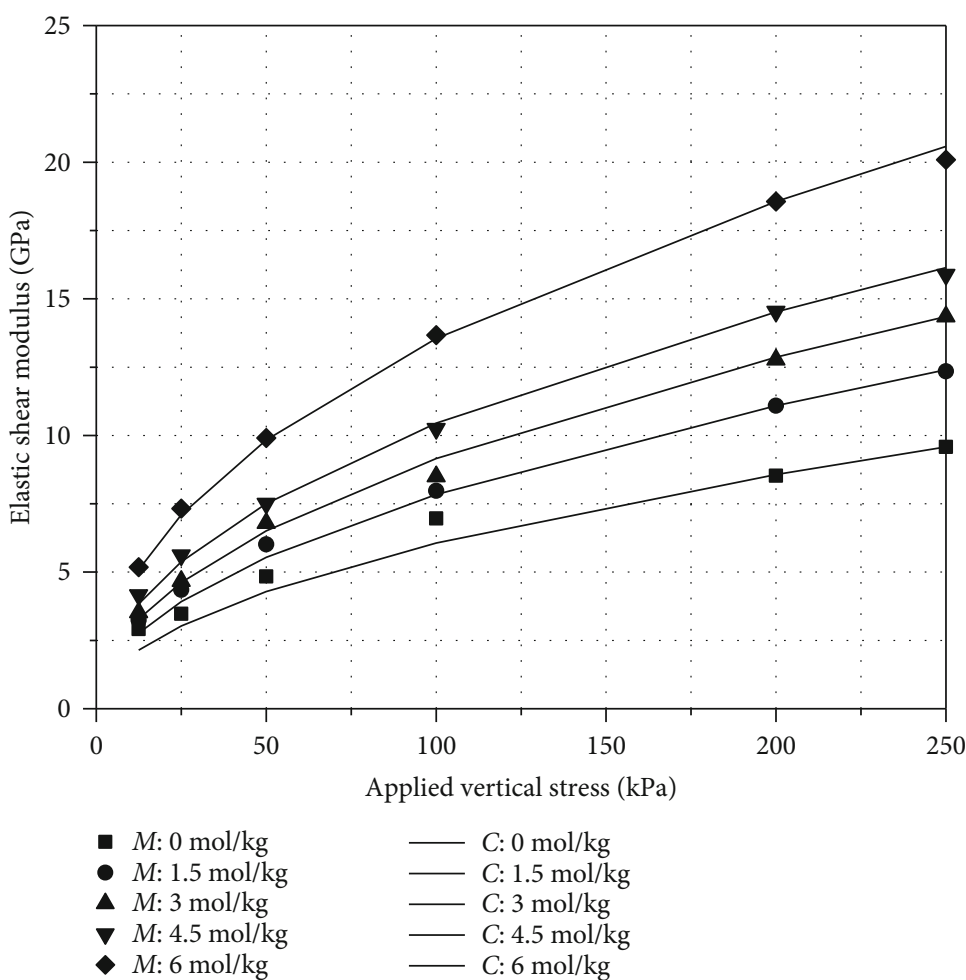

(b) $\mathrm{CaCl}_{2}$

FIgURE 13: Validation of the $G_{0}$ model under different salinity conditions. $M$ : measured values; $C$ : calculated values. 
TABLE 3: The properties of reproduced specimens.

\begin{tabular}{|c|c|c|c|c|c|c|}
\hline $\begin{array}{l}\text { Salt } \\
\text { type }\end{array}$ & $\begin{array}{l}\text { Salt concentration } \\
(\mathrm{mol} / \mathrm{kg})\end{array}$ & $\begin{array}{c}\text { Moisture } \\
\text { content }(\%)\end{array}$ & $\begin{array}{l}\text { Dry density } \\
\left(\mathrm{g} / \mathrm{cm}^{3}\right)\end{array}$ & $\begin{array}{l}\text { Void } \\
\text { ratio }\end{array}$ & $\begin{array}{l}\text { Predicted thermal conductivity } \\
\qquad\left(\mathrm{W} \mathrm{m}^{-1} \mathrm{~K}^{-1}\right)\end{array}$ & $\begin{array}{l}\text { Measured thermal conductivity } \\
\qquad\left(\mathrm{W} \mathrm{m}^{-1} \mathrm{~K}^{-1}\right)\end{array}$ \\
\hline \multirow{3}{*}{ None } & \multirow{3}{*}{0} & 18.995 & 1.537 & 0.707 & 1.344 & 1.371 \\
\hline & & 21.173 & 1.556 & 0.686 & 1.420 & 1.435 \\
\hline & & 23.373 & 1.531 & 0.714 & 1.428 & 1.461 \\
\hline \multirow{13}{*}{$\mathrm{NaCl}$} & \multirow{3}{*}{1.5} & 19.429 & 1.563 & 0.678 & 1.398 & 1.410 \\
\hline & & 21.205 & 1.566 & 0.675 & 1.371 & 1.455 \\
\hline & & 23.038 & 1.553 & 0.689 & 1.376 & 1.475 \\
\hline & \multirow{3}{*}{3} & 19.069 & 1.580 & 0.660 & 1.419 & 1.363 \\
\hline & & 20.975 & 1.587 & 0.653 & 1.370 & 1.417 \\
\hline & & 23.255 & 1.566 & 0.675 & 1.440 & 1.435 \\
\hline & \multirow{3}{*}{4.5} & 18.733 & 1.590 & 0.650 & 1.373 & 1.326 \\
\hline & & 20.530 & 1.593 & 0.647 & 1.384 & 1.373 \\
\hline & & 23.014 & 1.568 & 0.673 & 1.353 & 1.390 \\
\hline & \multirow{4}{*}{6} & 14.988 & 1.588 & 0.652 & 1.163 & 1.187 \\
\hline & & 17.154 & 1.653 & 0.587 & 1.358 & 1.343 \\
\hline & & 20.805 & 1.615 & 0.624 & 1.379 & 1.372 \\
\hline & & 22.832 & 1.565 & 0.676 & 1.322 & 1.339 \\
\hline \multirow{15}{*}{$\mathrm{CaCl}_{2}$} & \multirow{3}{*}{1.5} & 18.285 & 1.627 & 0.613 & 1.430 & 1.431 \\
\hline & & 19.732 & 1.644 & 0.595 & 1.462 & 1.497 \\
\hline & & 22.073 & 1.598 & 0.641 & 1.413 & 1.478 \\
\hline & \multirow{3}{*}{3} & 16.874 & 1.629 & 0.610 & 1.326 & 1.313 \\
\hline & & 19.502 & 1.644 & 0.595 & 1.377 & 1.404 \\
\hline & & 21.322 & 1.610 & 0.630 & 1.367 & 1.392 \\
\hline & \multirow{4}{*}{4.5} & 15.748 & 1.645 & 0.594 & 1.211 & 1.238 \\
\hline & & 17.463 & 1.671 & 0.570 & 1.308 & 1.324 \\
\hline & & 19.191 & 1.660 & 0.580 & 1.316 & 1.350 \\
\hline & & 21.051 & 1.613 & 0.626 & 1.315 & 1.319 \\
\hline & \multirow{5}{*}{6} & 13.236 & 1.620 & 0.619 & 1.134 & 1.086 \\
\hline & & 15.142 & 1.675 & 0.566 & 1.225 & 1.224 \\
\hline & & 17.156 & 1.702 & 0.541 & 1.327 & 1.323 \\
\hline & & 18.828 & 1.680 & 0.561 & 1.327 & 1.332 \\
\hline & & 21.198 & 1.633 & 0.607 & 1.297 & 1.313 \\
\hline
\end{tabular}

mass of added salt $(M)$, salt concentration $(\theta)$, and moisture content $(\omega)$ were incorporated into grain shape coefficients $g_{a s}, g_{b s}$, and $g_{c s}$ of $F_{s}$ :

$$
\begin{aligned}
& g_{a s}=g_{b s}=\lg \left(e^{(M \cdot \theta \cdot \omega) / 150}+0.5\right), \\
& g_{c s}=\lg \left(e^{(M \cdot \theta \cdot \omega) / 300}+0.5\right) .
\end{aligned}
$$

According to Farouki [26],

$$
F_{a}=\frac{1}{3}\left[\frac{2}{1+\left(\left(K_{a} / K_{w}\right)-1\right) \cdot g_{a a}}+\frac{1}{1+\left(\left(K_{a} / K_{w}\right)-1\right) \cdot g_{c a}}\right] \text {, }
$$

where $g_{a a}=0.333-\left(\left(V_{a} / V\right) / n\right)(0.333-0.035)$ and $g_{c a}=$ $1-2 g_{a}$.
Since there is no available thermal conductivity data of saline soil from the literature, several salt-affected soil samples were reproduced and tested to evaluate the model performance. The properties of reproduced specimens are listed in Table 3, and model performance is shown in Figure 14. It shows that the model prediction agreed with measured values well with the deviation of approximately $5 \%$. Figure 15 shows the comparison among different thermal conductivity predictive models. It can be seen that most of the predicted values from other models proposed in the literature were higher than the measured values. Since the influences of salt are not considered in these models, the microstructural change on the heat conduction path is underestimated, thus causing overestimation of the thermal conductivity of saline soils. Based on the above analyses, it can be concluded that the proposed model is capable of predicting the salt-affected soil's thermal conductivity. 


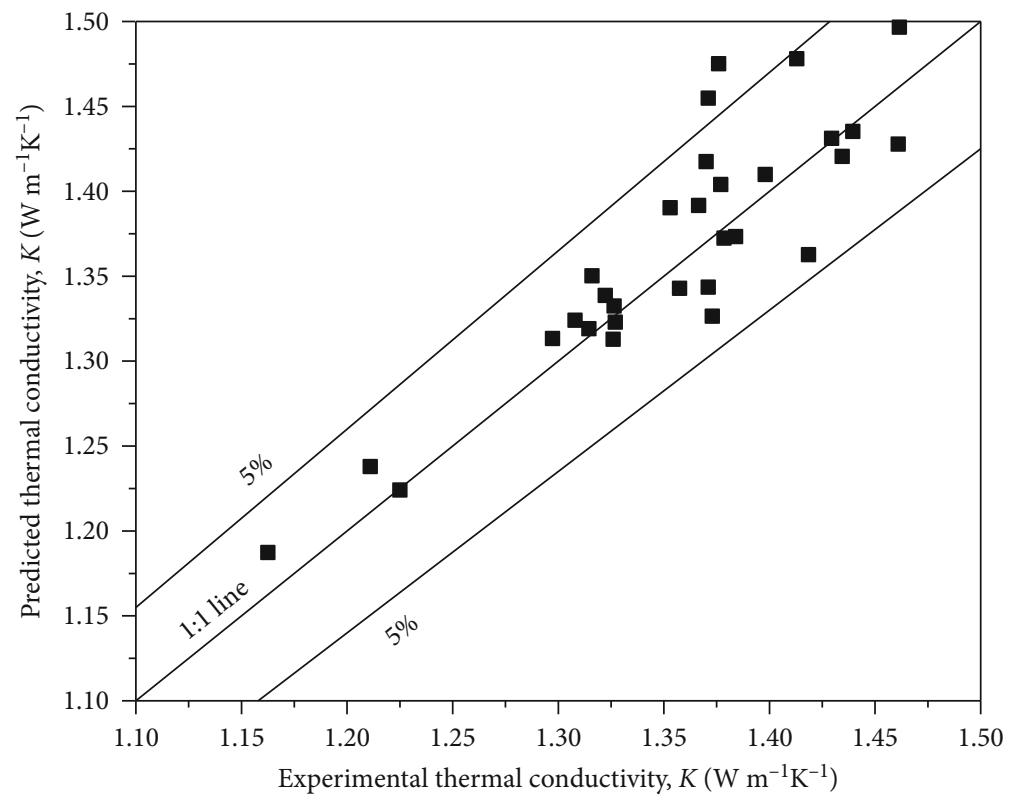

FIgURE 14: Performance of the $K$ model by comparing predicted thermal conductivities and measured values.

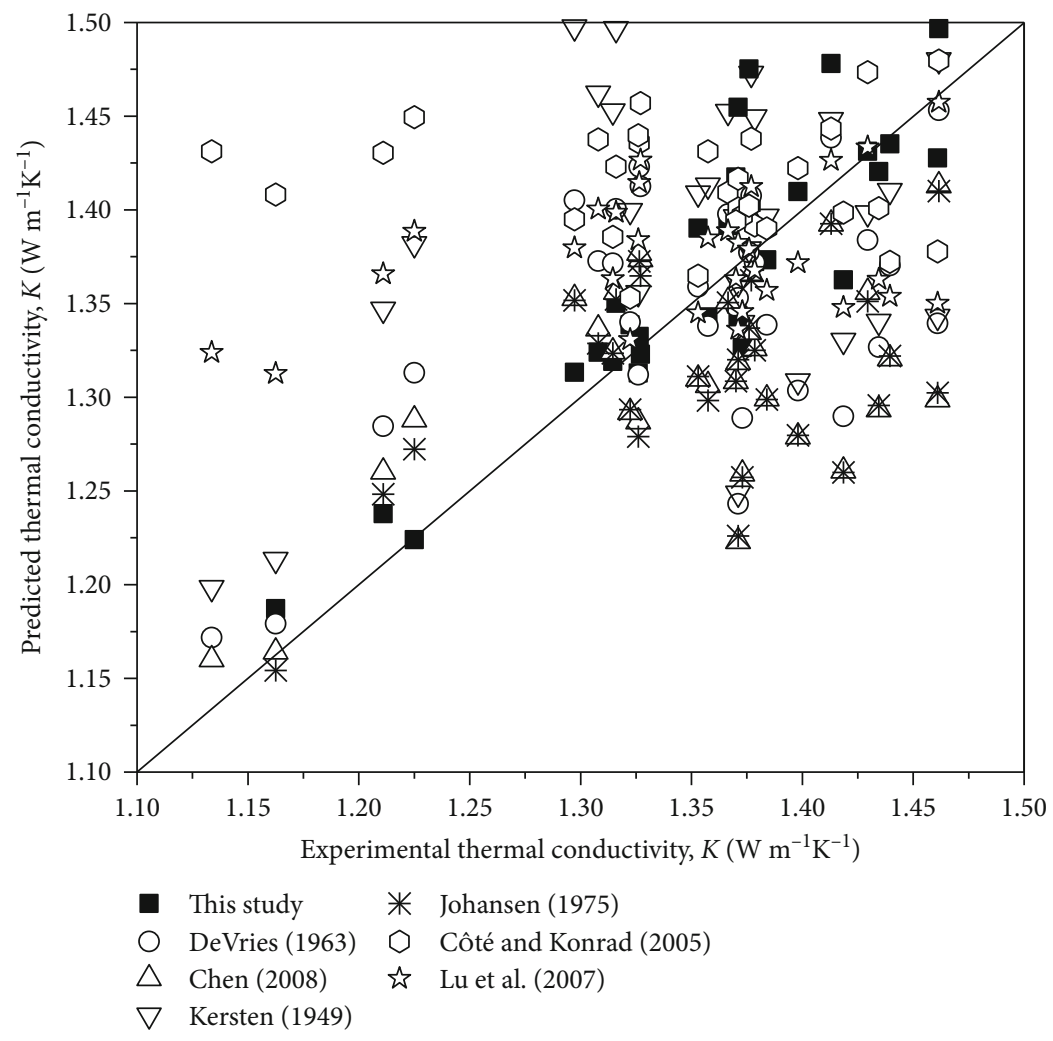

FIGURE 15: Comparison between different thermal conductivity predictive models.

\section{Conclusions}

The mechanical and thermal properties of saline soils were systematically investigated in this study. Laboratory observations indicated that the addition of salt has nonnegligible influence on the thermal and mechanical performances of natural soils because the salt can change the soil fabric and microstructure. As the salt concentration increased, the saline soil's bulk density increased, causing the shear wave to propagate faster. The shear strength was also found to 
increase in salt-affected soil by comparison with untreated soil. As the compression loading increased, the difference of compressibility between salt-treated and salt-untreated soils gradually reduced. The higher the salt content is, the lower the compressibility will be, given the same vertical load, which is attributed to the destruction of microstructures due to salt attack. The decrease of thermal conductivity of saline soils as the soil salt content increase is attributed to the salt induced flocculation and aggregation which affects the heat conduction path. The flocculation and aggregation of saline soils at the microscale creates many air voids (intra-aggregate pores and interaggregate pores) with relatively low thermal conductivity, as well as salt solutions, which coexisted in the soil pores, thus significantly decreasing the efficiency of the heat transfer process. By considering the soil salt contents, two theoretical models were developed for the first time to predict the $G_{0}$ and $K$ of saline soils. Both literature data and experimental results were employed to validate the proposed models. The comparisons showed good model performance which indicated the model robustness for predicting the thermal-mechanical properties of saline soils; however, further studies are still desired to extend the models to a wider range of soil types.

\section{Data Availability}

The data used to support the findings of this study are available from the corresponding author upon request.

\section{Conflicts of Interest}

The authors declare that they have no conflicts of interest.

\section{Acknowledgments}

The authors wish to acknowledge the financial support received from the National Natural Science Foundation of China (No. 51578230).

\section{References}

[1] Z. Q. Wang, S. Q. Zhu, and R. P. Yu, Salt-Affected Soils of China (in Chinese), Beijing Science Press, China, 1993.

[2] D. Adam and R. Markiewicz, "Energy from earth-coupled structures, foundations, tunnels and sewers," Géotechnique, vol. 59, no. 3, pp. 229-236, 2009.

[3] J. Tao, Y. Wu, D. Elsworth, P. Li, and Y. Hao, "Coupled thermo-hydro-mechanical-chemical modeling of permeability evolution in a $\mathrm{CO}_{2}$-circulated geothermal reservoir," Geofluids, vol. 2019, 15 pages, 2019.

[4] X. Shi, S. Finsterle, K. Zhang, and D. Lu, "Advances in multiphase flow and transport in the subsurface environment," Geofluids, vol. 2018, Article ID 2906326, 2 pages, 2018.

[5] A. Santilano, E. Trumpy, G. Gola et al., "A methodology for assessing the favourability of geopressured-geothermal systems in sedimentary basin plays: a case study in Abruzzo (Italy)," Geofluids, vol. 2019, Article ID 4503943, 28 pages, 2019.

[6] M. Saroli, M. Albano, G. Giovinco et al., "A macroscale hydrogeological numerical model of the Suio hydrothermal system
(Central Italy)," Geofluids, vol. 2019, Article ID 5485068, 16 pages, 2019.

[7] J. M. Marques, P. M. Carreira, L. A. Aires-Barros, F. A. Monteiro Santos, M. Antunes da Silva, and P. Represas, "Assessment of Chaves low-temperature $\mathrm{CO}_{2}$-rich geothermal system (N-Portugal) using an interdisciplinary geosciences approach," Geofluids, vol. 2019, Article ID 1379093, 24 pages, 2019.

[8] B. Wu, T. Ma, G. Feng, Z. Chen, and X. Zhang, "An approximate solution for predicting the heat extraction and preventing heat loss from a closed-loop geothermal reservoir," Geofluids, vol. 2017, Article ID 2041072, 17 pages, 2017.

[9] H. Brandl, "Energy foundations and other thermo-active ground structures," Géotechnique, vol. 56, no. 2, pp. 81-122, 2006.

[10] H. Demir, A. Koyun, and G. Temir, "Heat transfer of horizontal parallel pipe ground heat exchanger and experimental verification," Applied Thermal Engineering, vol. 29, no. 2-3, pp. 224-233, 2009.

[11] J. Darkwa, G. Kokogiannakis, C. L. Magadzire, and K. Yuan, "Theoretical and practical evaluation of an earth-tube (E-tube) ventilation system," Energy and Buildings, vol. 43, no. 2-3, pp. 728-736, 2011.

[12] V. Bansal, R. Misra, G. D. Agarwal, and J. Mathur, "Transient effect of soil thermal conductivity and duration of operation on performance of earth air tunnel heat exchanger," Applied Energy, vol. 103, pp. 1-11, 2013.

[13] G. Gan, "Dynamic interactions between the ground heat exchanger and environments in earth-air tunnel ventilation of buildings," Energy and Buildings, vol. 85, pp. 12-22, 2014.

[14] L. Laloui and A. Di Donna, Energy Geostructures: Innovation in Underground Engineering, John Wiley \& Sons, Inc., 2013.

[15] N. Zhang and H. T. He, "Comparative performance of soil thermal conductivity prediction models for geothermal applications," Fourth Geo-China International Conference, 2016, Shandong, China, July 2016, 2016.

[16] M. Gao, T. Li, T. Wei, and L. Meng, "A statistical constitutive model considering deterioration for brittle rocks under a coupled thermal-mechanical condition," Geofluids, vol. 2018, Article ID 3269423, 10 pages, 2018.

[17] N. H. Abu-Hamdeh and R. C. Reeder, "Soil thermal conductivity," Soil Science Society of America Journal, vol. 64, no. 4, article 1285, 2000.

[18] O. Johansen, "Thermal conductivity of soils," Ph.D. thesis, University of Trondheim, Trondheim, Norway, 1975.

[19] Y. Dong, J. S. McCartney, and N. Lu, "Critical review of thermal conductivity models for unsaturated soils," Geotechnical and Geological Engineering, vol. 33, no. 2, article 9843, pp. 207-221, 2015.

[20] N. Zhang, X. Yu, A. Pradhan, and A. J. Puppala, “Thermal conductivity of quartz sands by thermo-time domain reflectometry probe and model prediction," vol. 27, Tech. Rep. 12, Article ID 04015059, Journal of Materials in Civil Engineering, 2015.

[21] R. Shu, T. Yin, and X. Li, "Effect of heating rate on the dynamic compressive properties of granite," Geofluids, vol. 2019, Article ID 8292065, 12 pages, 2019.

[22] R. M. Van and H. F. Winterkorn, "Structural and textural influences on thermal conductivity of soils," in Proceedings of 38th Annual Meeting, Highway Research Board of the National Research Council, Washington DC, USA, January 1959.

[23] D. A. DeVries, "Thermal properties of soils," in Physics of Plant Environment, W. R. Wijk, Ed., John Wiley and Sons, New York, NY, USA, 1963. 
[24] A. M. Globus and S. K. Rozenshtok, "Nonisothermal internal moisture exchange in an incompletely saturated porous medium with alkaline interstitial solution," Soviet Soil Science, vol. 21, pp. 111-115, 1989.

[25] K. Noborio and K. J. McInnes, "Thermal conductivity of saltaffected soils," Soil Science Society of America Journal, vol. 57, no. 2, p. 329, 1993.

[26] O. T. Farouki, "The thermal properties of soils in cold regions," Cold Regions Science and Technology, vol. 5, no. 1, pp. 67-75, 1981.

[27] K. Terzaghi, "The shear resistance of saturated soils," in Proceedings of 1st International Conference Soil Mechanics Foundation Engineering, pp. 54-56, Cambridge, MA, USA, 1936.

[28] J. C. Santamarina, A. Klein, and M. A. Fam, "Soils and waves: particulate materials behavior, characterization and process monitoring," Journal of Soils and Sediments, vol. 1, no. 2, article 130, 2001.

[29] Y. T. Sup, "Mechanical and thermal study of hydrate bearing sediments," Ph.D thesis, Georgia Institute of Technology, Atlanta GA, USA, 2005.

[30] X. Kang, G. C. Kang, and B. Bate, "Measurement of stiffness anisotropy in kaolinite using bender element tests in a floating wall consolidometer," vol. 37, Tech. Rep. 5, Article ID 20120205, Geotechnical Testing Journal, 2014.

[31] J. K. Mitchell and K. Soga, "Fundamentals of soil behavior," Soil Science, vol. 158, no. 1, p. 74, 2006.

[32] B. P. Warkentin and R. N. Yong, "Shear strength of montmorillonite and kaolinite related to interparticle forces," in Proceedings of the Ninth National Conference on Clays and Clay Minerals, pp. 210-218, Lafayette, IN, USA, 1962.

[33] X. P. Nguyen, Y. J. Cui, A. M. Tang, Y. F. Deng, X. L. Li, and L. Wouters, "Effects of pore water chemical composition on the hydro-mechanical behavior of natural stiff clays," Engineering Geology, vol. 166, pp. 52-64, 2013.

[34] S. K. Vanapalli, D. G. Fredlund, D. E. Pufahl, and A. W. Clifton, "Model for the prediction of shear strength with respect to soil suction," Canadian Geotechnical Journal, vol. 33, no. 3, pp. 379-392, 1996.

[35] B. M. Das, "Shear strength of soils," in Advanced Soil Mechanics, 469-584, Taylor \& Francis, Boca Raton, 5th edition, 2019.

[36] U. Koyluoglu, "Soil mechanics for unsaturated soils: D. G. Fredlund \& H. Rahardjo. John Wiley and Sons, 1993. ISBN 0-471-85008-X. 517 pp," Soil Dynamics and Earthquake Engineering, vol. 12, no. 7, pp. 449-450, 1993.

[37] Y. He, K.-n. Zhang, and D.-y. Wu, "Experimental and modeling study of soil water retention curves of compacted bentonite considering salt solution effects," Geofluids, vol. 2019, Article ID 4508603, 11 pages, 2019.

[38] G. Mesri and R. E. Olson, "Mechanisms controlling the permeability of clays," Clays and Clay Minerals, vol. 19, no. 3, pp. 151-158, 1971.

[39] O. Wiener, "Abhandl math-phys Klassesdichs, ges," Wissenseh, vol. 32, p. 509, 1912

[40] Y. L. Rastorguev and Y. A. Ganiev, "Thermal conductivity of solutions," Journal of Engineering Physics, vol. 14, no. 4, pp. 372-377, 1968.

[41] X. Kang and L. Ge, "Enhanced series-parallel model for estimating the time-dependent thermal conductivity of fly ash soil mixtures," Granular Matter, vol. 17, no. 5, pp. 579-592, 2015.
[42] H. Kurt and M. Kayfeci, "Prediction of thermal conductivity of ethylene glycol-water solutions by using artificial neural networks," Applied Energy, vol. 86, no. 10, pp. 2244-2248, 2009.

[43] X. Kang, L. Ge, G. C. Kang, and C. Mathews, "Laboratory investigation of the strength, stiffness, and thermal conductivity of fly ash and lime kiln dust stabilised clay subgrade materials," Road Materials and Pavement Design, vol. 16, no. 4, pp. 928-945, 2015.

[44] N. Zhang and Z. Wang, "Review of soil thermal conductivity and predictive models," International Journal of Thermal Sciences, vol. 117, pp. 172-183, 2017.

[45] J. H. Atkinson and G. Salfors, "Experimental determination of stress-strain-time characteristics in laboratory and in situ tests," in Proceedings of the 10th European Conference on Soil Mechanics and Foundation Engineering, Florence, 1991.

[46] J. Xu and C. Zhou, "A simple model for the hysteretic elastic shear modulus of unsaturated soils," Journal of Zhejiang University-Science A, vol. 17, no. 7, pp. 589-596, 2016.

[47] C. Mancuso, R. Vassallo, and A. d'Onofrio, "Small strain behavior of a silty sand in controlled-suction resonant column - torsional shear tests," Canadian Geotechnical Journal, vol. 39, no. 1, pp. 22-31, 2003.

[48] C. W. W. Ng and S. Y. Yung, "Determination of the anisotropic shear stiffness of an unsaturated decomposed soil," Géotechnique, vol. 58, no. 1, pp. 23-35, 2008.

[49] A. Sawangsuriya, T. B. Edil, and P. J. Bosscher, "Modulus-suction-moisture relationship for compacted soils in postcompaction state," Journal of Geotechnical and Geoenvironmental Engineering, vol. 135, no. 10, pp. 1390-1403, 2009.

[50] M. Biglari, C. Mancuso, A. d'Onofrio, M. K. Jafari, and A. Shafiee, "Modelling the initial shear stiffness of unsaturated soils as a function of the coupled effects of the void ratio and the degree of saturation," Computers and Geotechnics, vol. 38, no. 5, article S0266352X11000656, pp. 709-720, 2011.

[51] A. Khosravi and J. S. McCartney, "Impact of hydraulic hysteresis on the small-strain shear modulus of low plasticity soils," Journal of Geotechnical and Geoenvironmental Engineering, vol. 138, no. 11, pp. 1326-1333, 2012.

[52] W. T. Oh and S. K. Vanapalli, "Semi-empirical model for estimating the small-strain shear modulus of unsaturated nonplastic sandy soils," Geotechnical and Geological Engineering, vol. 32, no. 2, pp. 259-271, 2014.

[53] K. S. Wong, D. Mašín, and C. W. W. Ng, "Modelling of shear stiffness of unsaturated fine grained soils at very small strains," Computers and Geotechnics, vol. 56, pp. 28-39, 2014.

[54] Y. Dong, N. Lu, and J. S. McCartney, "Unified model for smallstrain shear modulus of variably saturated soil," Journal of Geotechnical and Geoenvironmental Engineering, vol. 142, no. 9, article 04016039, 2016.

[55] Y. Dong and N. Lu, "Correlation between small-strain shear modulus and suction stress in capillary regime under zero total stress conditions," Journal of Geotechnical and Geoenvironmental Engineering, vol. 142, no. 11, p. 04016056, 2016.

[56] B. Hardin and W. Black, "Sand stiffness under various triaxial stresses:", Journal of Terramechanics, vol. 4, no. 3, p. 70, 1967.

[57] S. Shibuya, S. C. Hwang, and T. Mitachi, "Elastic shear modulus of soft clays from shear wave velocity measurement," Géotechnique, vol. 47, no. 3, pp. 593-601, 1997.

[58] G. R. McDowell and M. D. Bolton, "Micro mechanics of elastic soil," Soils and Foundations, vol. 41, no. 6, pp. 147-152, 2001. 
[59] S. Oztoprak and M. D. Bolton, "Stiffness of sands through a laboratory test database," Géotechnique, vol. 63, no. 1, pp. 54-70, 2013.

[60] F. Donazzi, E. Occhini, and A. Seppi, "Soil thermal and hydrological characteristics in designing underground cables," Proceedings of the Institution of Electrical Engineers, vol. 126, no. 6 , p. $506,1979$.

[61] M. V. B. B. Gangadhara Rao and D. N. Singh, "A generalized relationship to estimate thermal resistivity of soils," Canadian Geotechnical Journal, vol. 36, no. 4, pp. 767-773, 1999.

[62] V. R. Tarnawski, F. Gori, B. Wagner, and G. D. Buchan, "Modelling approaches to predicting thermal conductivity of soils at high temperatures," International Journal of Energy Research, vol. 24, no. 5, pp. 403-423, 2000.

[63] V. R. Tarnawski and F. Gori, "Enhancement of the cubic cell soil thermal conductivity model," International Journal of Energy Research, vol. 26, no. 2, pp. 143-157, 2002.

[64] F. Gori, "A theoretical model for predicting the effective thermal conductivity of unsaturated frozen soils," in Proceedings of 4th International Conference on Permafrost, pp. 363-368, Fairbanks AK, USA, 1983.

[65] F. Gori and S. Corasaniti, "Theoretical prediction of the soil thermal conductivity at moderately high temperatures," Journal of Heat Transfer, vol. 124, no. 6, pp. 1001-1008, 2002.

[66] J. Côté and J.-M. Konrad, "A generalized thermal conductivity model for soils and construction materials," Canadian Geotechnical Journal, vol. 42, no. 2, pp. 443-458, 2005.

[67] S. Lu, T. Ren, Y. Gong, and R. Horton, “An improved model for predicting soil thermal conductivity from water content at room temperature," Soil Science Society of America Journal, vol. 71, no. 1, p. 8, 2007.

[68] S. K. Haigh, "Thermal conductivity of sands," Géotechnique, vol. 62, no. 7, pp. 617-625, 2012.

[69] M. S. Kersten, "Laboratory research for the determination of the thermal properties of soils," University of Minnesota Engineering Experiment Station, Minneapolis, MN, USA, 1949.

[70] S. X. Chen, "Thermal conductivity of sands," Heat and Mass Transfer, vol. 44, no. 10, article 357, pp. 1241-1246, 2008. 

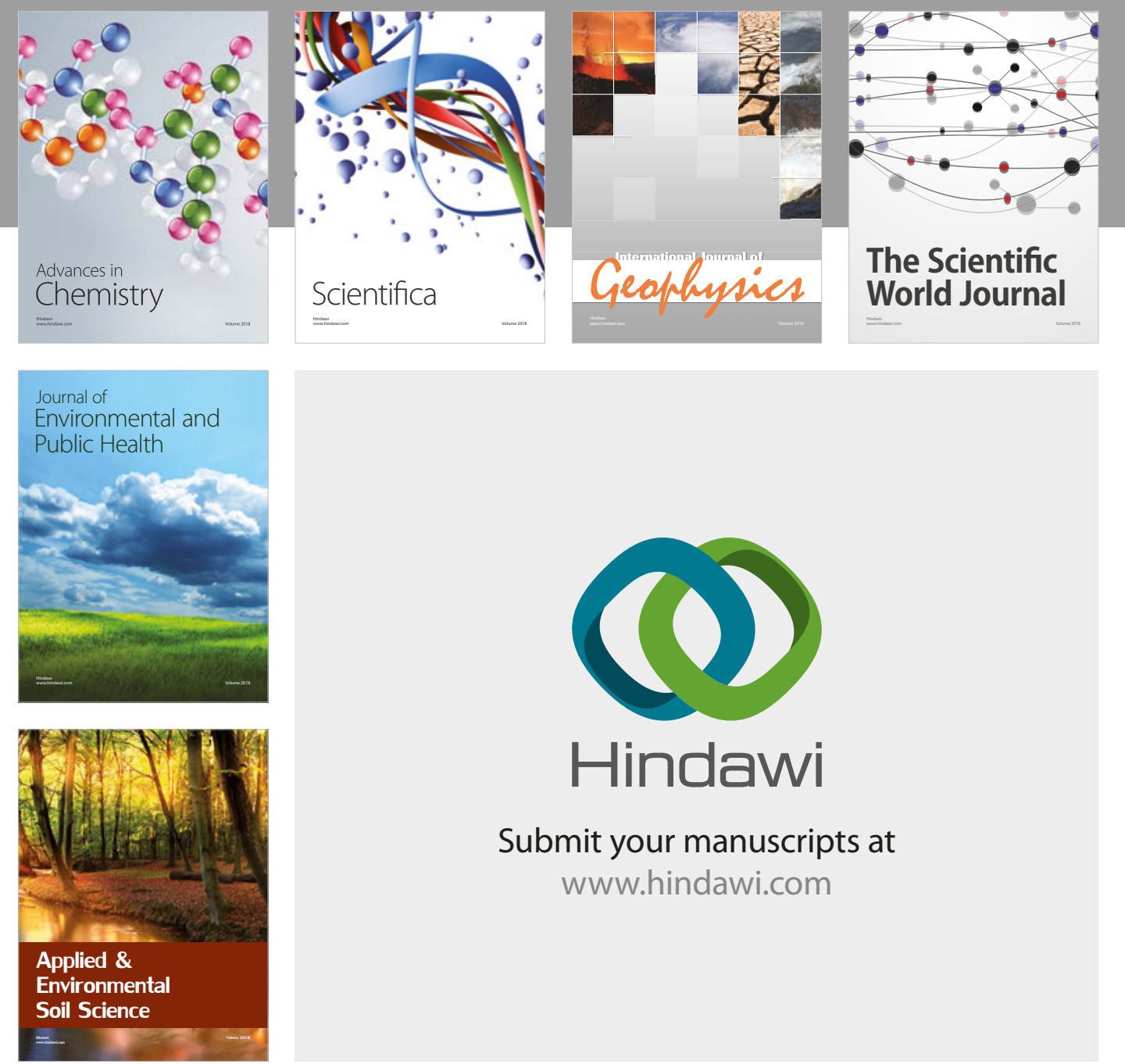

The Scientific

\section{World Journal}
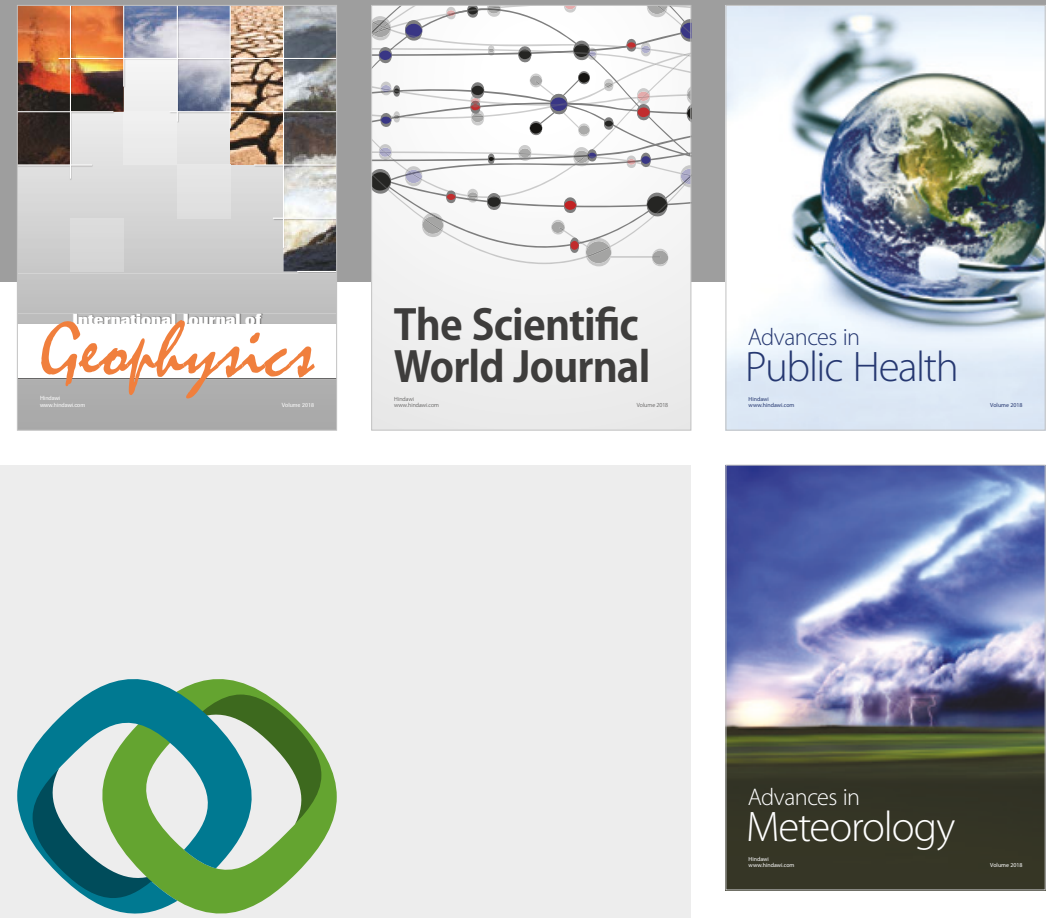

Advan

Public Health

\section{Hindawi}

Submit your manuscripts at

www.hindawi.com
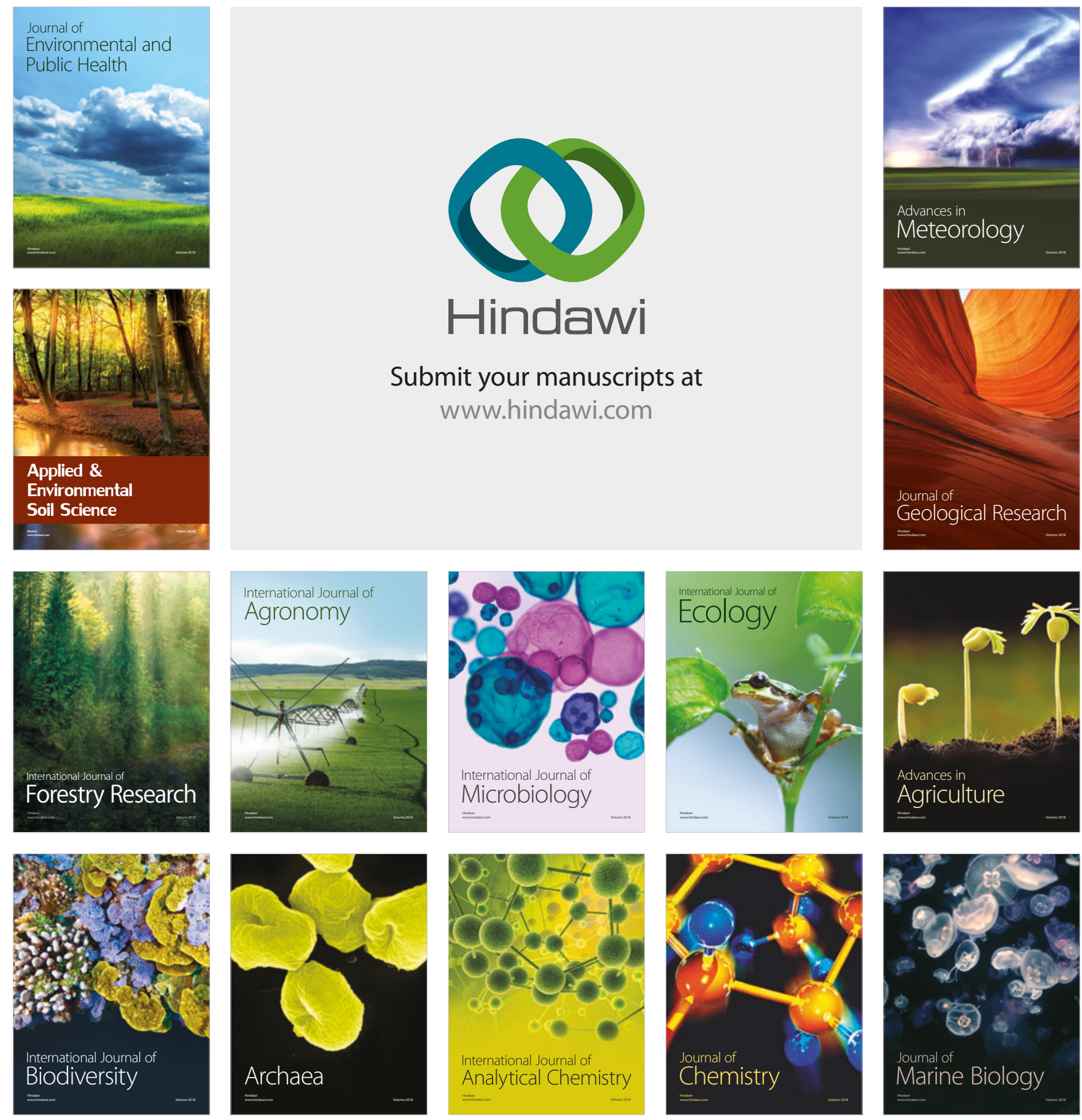